\title{
The Roman Catholic Ordinary Mass from circa 1750 to circa 1820: A Selected Bibliography
}

\author{
Letícia Gabriele Grützmann Januario \\ West Virginia University, Iggrutzmannjanuario@mix.wvu.edu
}

Follow this and additional works at: https://researchrepository.wvu.edu/etd

Part of the Music Education Commons, Musicology Commons, Music Pedagogy Commons, Music Performance Commons, Music Practice Commons, Music Theory Commons, and the Other Music Commons

\section{Recommended Citation}

Grützmann Januario, Letícia Gabriele, "The Roman Catholic Ordinary Mass from circa 1750 to circa 1820: A Selected Bibliography" (2020). Graduate Theses, Dissertations, and Problem Reports. 7696.

https://researchrepository.wvu.edu/etd/7696

This Dissertation is protected by copyright and/or related rights. It has been brought to you by the The Research Repository @ WVU with permission from the rights-holder(s). You are free to use this Dissertation in any way that is permitted by the copyright and related rights legislation that applies to your use. For other uses you must obtain permission from the rights-holder(s) directly, unless additional rights are indicated by a Creative Commons license in the record and/ or on the work itself. This Dissertation has been accepted for inclusion in WVU Graduate Theses, Dissertations, and Problem Reports collection by an authorized administrator of The Research Repository @ WVU.

For more information, please contact researchrepository@mail.wvu.edu. 
Graduate Theses, Dissertations, and Problem Reports

2020

The Roman Catholic Ordinary Mass from circa 1750 to circa 1820: A Selected Bibliography

Letícia Gabriele Grützmann Januario

Follow this and additional works at: https://researchrepository.wvu.edu/etd

Part of the Music Education Commons, Musicology Commons, Music Pedagogy Commons, Music Performance Commons, Music Practice Commons, Music Theory Commons, and the Other Music Commons 
The Roman Catholic Ordinary Mass from circa 1750 to circa 1820:

A Selected Bibliography

\author{
Letícia Grützmann
}

Research Project submitted to the

College of Creative Arts at

West Virginia University

in partial fulfillment of the requirements for the degree of

Doctor of Music Arts in Conducting

\author{
Mitchell Arnold, D.M.A., Chair \\ Kym Scott, D.M.A. \\ Laura Knoop Very, M.M. \\ Eve Faulkes, M.F.A.
}

School of Music

Morgantown, West Virginia

2020

Keywords: Ordinary Masses, Mass, Classical Mass, Classical Music, Viennese Masses. 


\section{ABSTRACT \\ The Roman Catholic Ordinary Mass from circa 1750 to circa 1820: A Selected Bibliography}

\section{Letícia Grützmann}

Orchestrated masses from the 18th century and early years of the 19th century provide a valuable source of repertoire for contemporary choral conductors. This project will explore composers and works from circa 1750 to 1820 to provide choral conductors with a list of works suitable for programming based on the practical size of vocal and instrumental forces.

Western choral music was born in a church setting. Among all choral genres, the mass is the only genre composed throughout all eras, from medieval until the 20th century. The mass remained a prominent genre during the 18th century despite the secularizing influence of the Enlightenment. Unlike earlier choral masses, these masses reflected the growing interest in and influence of orchestral music. According to Chester L. Alwes (2015) "The dominant genre of Classic-Romantic period is undoubtedly that of the Mass ordinary for chorus, soloists, and orchestra. $^{1,}$

This paper will compile a catalog of masses featuring choir and orchestra as well as supplemental scholarly materials useful for interpretation and performance. The inventory will focus on the Roman Catholic Ordinary Masses from circa 1750 to circa 1820, using exclusively the Latin and Greek texts. In this document, the reader will also find a guide to research resources such as articles, theses, dissertations, books, and other written materials related to the

\footnotetext{
${ }^{1}$ The e-book version of this material has one abstract per chapter. This quote is from the ebook's abstract of chapter 12: Alwes, Chester L. A History of Western Choral Music. (New York: Oxford University Press, 2015).
} 
collected works. The scope of this review will be limited by the materials in English that are available through online search functions such as music databases including ProQuest Dissertations and Theses Global, JSTOR, Grove Music Online, Oxford Music Bibliographies, RILM Abstracts of Music Literature, Music Index Online, Wikipedia, Google, and others. 


$\begin{array}{lll}\text { Student Name: } & \frac{\text { Grutzman Januario }}{\text { (Last) }} & \begin{array}{c}\text { West Virginia University } \\ \text { Electronic Thesis and Dissertation } \\ \text { Committee Signature Form }\end{array} \\ \text { Student ID \#: } & \begin{array}{l}800156220 \\ \text { Leticia }\end{array} \\ \text { (First) } & \text { Non-wvu Email Account: } \frac{\text { leticiagrutzmann.j@gmail.com }}{\text { (Middle) }}\end{array}$

Degree:

Document Type:

$\begin{array}{cc}\text { Master's } & X \text { Doctorate } \\ \text { Thesis } & X \text { Dissertation }\end{array}$

Project/Problem Report

Document Title: The Roman Catholic Ordinary Mass from circa 1750 to circa 1820: A Selected Bibliography

Student Agreement:

I hereby certify that, if appropriate, I have obtained and attached hereto a written permission statement from the owners of each third party copyrighted matter to be included in my thesis, dissertation, project report, or other research material, allowing distribution as specified upon deposit.

I hereby grant to West Virginia University and its agents the non-exclusive license to archive and make accessible, under the conditions selected upon deposit, my above mentioned document in whole or in part in all forms of media, now or hereafter known. I retain ownership rights as specified in the WVU copyright policy to the copyright of the abovementioned document. I also retain the right to use in future works (such as articles or books) all or part of this abovementioned document.

\section{Review and Acceptance:}

The above mentioned document has been reviewed and accepted by the student's advisory committee. The undersigned agree to abide by the statements above, and agree that this Signature Form updates any and all previous Signature Forms submitted heretofore.

\begin{tabular}{|c|c|c|}
\hline Signed: & 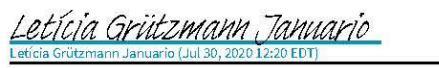 & Jul 30, 2020 \\
\hline \multirow{9}{*}{ Committee: } & $\begin{array}{l}\text { (Student) } \\
\text { Mitchell Amold }\end{array}$ & $\begin{array}{c}\text { (date) } \\
\text { Jul } 29,2020\end{array}$ \\
\hline & (Committee Chair) & (date) \\
\hline & (Committee Co-Chair or Committee Member) & (date) \\
\hline & 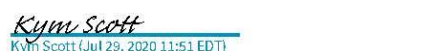 & Jul 29, 2020 \\
\hline & (Committee Member) & (date) \\
\hline & 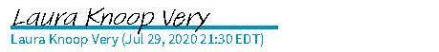 & Jul 29, 2020 \\
\hline & $\begin{array}{l}\text { (Committee Member) } \\
\text { we Faulfeed }\end{array}$ & $\begin{array}{c}\text { (date) } \\
\text { Jul } 30,2020\end{array}$ \\
\hline & (Committee Member) & (date) \\
\hline & (Committee Member) & (date) \\
\hline
\end{tabular}




\section{ACKNOWLEDGEMENTS}

It has been an honor to be a student at West Virginia University. I have had the opportunity to be guided by so many outstanding professors and human beings, and especially want to acknowledge the valuable members of my doctoral committee, Dr. Mitchell Arnold, Dr. Kym Scott, Professor Laura Very and Professor Eve Faulkes. I also want to acknowledge the great insights from my former research advisor, Dr. Evan MacCarthy, who has moved on to a different path before the conclusion of this document.

First and foremost, I want to thank my conducting Professor, Dr. Kym Scott who has guided me with great support throughout the five years at WVU, during my master's and doctoral degrees. I appreciate all the opportunities she has given to me that have allowed me to grow in a variety of manners through so many different and valuable experiences. I am thankful for her friendship and tireless dedication to anything I needed, and her patience with my "in development” English skills during the years. I am grateful for the trust she has laid on me by giving me a choir to teach completely by myself, and for unconditionally believing in my work with all the choirs. I thank her for all the great opportunities that gave me unique and unmeasurable chances to grow, and to become a better leader and a better contributor to the choral music world.

I am very thankful for other members of the WVU conducting faculty with whom I had the privilege to study. Dr. Mitchell Arnold gave me great advice for my doctorate recitals of choirs and orchestra, insights on my document research, and gave his time chairing this doctoral committee. Dr. Scott Tobias has been a great supporter of my projects, as well as a wonderful conducting professor. Professor John Hendricks III taught me during my master's degree, gave me my first experience conducting a symphonic band, and has continued to be a supporter over 
the years. The expertise and wisdom from these faculty members will always speak closely to me, and I hope to share the experiences I have received from them with my own students.

My deepest gratitude to Dr. Hope Koehler and Professor James Mitchell. They have given me great guidance in my vocal studies, along with other professors of the voice department, Professor Laura Very and Professor Rob Chafin.

I highly appreciate my graduate studies advisor, Professor Cynthia Anderson. She always advised me in the most helpful manner that I could ever expect from a graduate advisor, giving me support and solutions for my best interest.

I extend my appreciation to Dean Dr. Keith Jackson, Associate Dean John Hendricks, and to the Director of School of Music, Dr. Michael Ibrahim, for their help as I move to a new path. Their insights have been crucial to my professional achievements. I also acknowledge the Creative Arts Center staff that have been so supportive along the way with advice and comfort in difficult times.

I also want to thank my conducting colleagues, the future Dr. Pingyi Song, the future Dr. Natalie Shaffer, Dr. Ryan Keeling, Dr. Joe Stuligross, and Dr. Matthew McCurry. They have each been with me, at some point, during the five years of this journey. Their support and friendship have helped me get through challenging times, and more than that, they filled my journey with great joy and knowledge.

Special thanks to my colleague, the future Dr. Jacob Kopcienski, who gave me essential advice as I built my research prospectus. It made my life a lot easier to have the help of this very caring friend. 
My sincere gratitude to my friend Michelle, that gave me some last-minute grammar insights but also has helped me with so much during this time while writing this dissertation and preparing for job searches, all at the same time.

I also want to include my dear conducting Professor from Brazil, Dr. Jocelei Bohrer. He shared with me his knowledge in several capacities that allowed me to grow and to travel overseas to continue my education.

I want to thank the singers that I have had the pleasure of conducting and teaching, especially the singers of the Vox Principalis Choral Association, along with our accompanist, Marguerite Bostonia, and the WVU Women's Chorus, along with our accompanist, Yiwen Zhang. I will be forever grateful for the opportunity they gave me to lead them, and to grow as a musician, a conductor, and a person.

There are not enough words to thank my beloved husband, André Januário, who has been with me during this journey, while also in the midst of his own academic journey. The challenges of studying for a doctoral degree in a foreign country were just as big as we had imagined maybe more emotionally demanding than we expected - but I am grateful that we made it together and soon we will both have completed our doctoral degrees.

Finally, I am grateful for the unending support and love that I have received from my parents, Mr. Ari and Mrs. Ingrid Grützmann, and my sisters Stella and Ariane. They have always, unconditionally, encouraged me and cheered me on, and without my family, this journey never would have happened. 


\section{TABLE OF CONTENTS}

\section{Page}

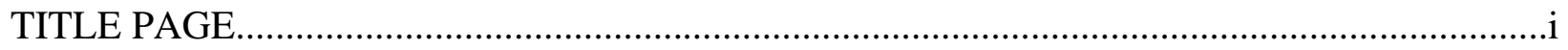

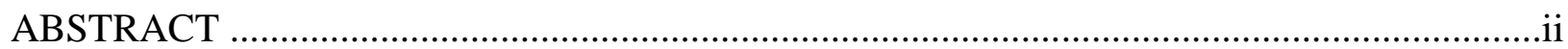

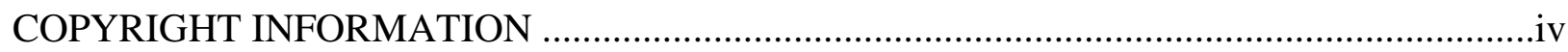

COMMITTEE SIGNATURE PAGE.....................................................................................

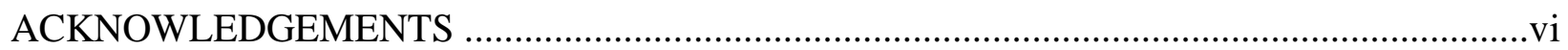

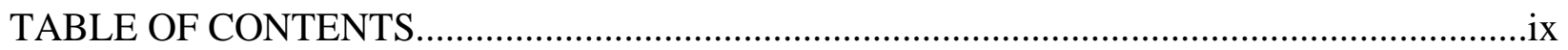

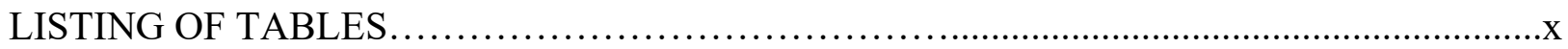

INTRODUCTION

Background and Purpose of Study ..................................................................................

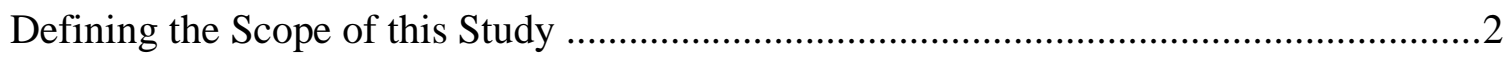

THE MASS COMPOSITIONS FROM CIRCA 1750 TO CIRCA 1820........................................

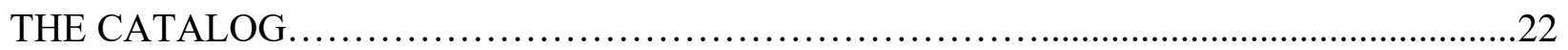

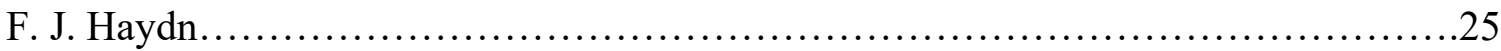

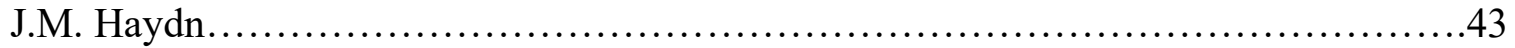

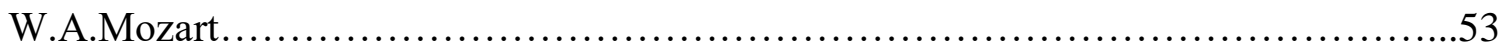

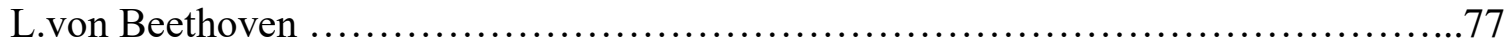

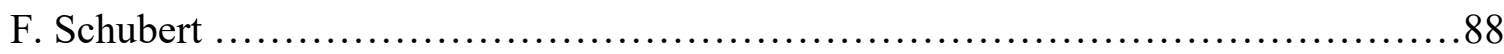

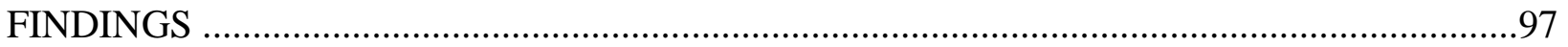




\section{Listing of Tables}

Table 1.1 German and Austrian Composers ...........................................6

Table 1.2. Italian and French Composers.............................................. 9

Table 1.3. Lesser-known Italian Composers who were employed in churches .................10 


\section{INTRODUCTION \\ Background and Purpose}

Despite extensive exploration, there is little material dedicated exclusively to inform and to explore the subject "mass" in its entirety from the emergence of the genre until the 20thcentury, from the perspective of a conductor and a student studying choral music. I believe that by exploring choral music through the genre "mass," a learner can obtain a comprehensive perspective of the development of sacred choral music throughout the eras.

I have been asked several times what the standard works of choral music are. It is a tough question to answer. Generally, when we speak about standard works, we consider pieces of relevant literature that are widely known, at least in the music community, and that represent and provide structural and fundamental knowledge of the music from the specific genre and period. I believe that the study of the masses can give an understanding of the specific periods, not only of choral music but of the history of music in general. For example, if we consider that masses during the classical period have been influenced by operatic and concert music genres in such a manner that those forms were taken into the church, we can understand the impact that the Enlightenment made in music. According to Homer Ulrich,

The early eighteenth century had witnessed the rise of a system of thought - the Enlightenment - that rejected much traditional authority, aristocratic privilege, empty formalism, and the outworn ritual of the church. Chief among these new ideas were the enthronement of freedom in the arts, a commonsensical approach to social and scientific problems, a faith in the value of human instincts and "natural" feelings, and a belief that the common man should be exposed to as much culture and education as he could absorb.

The new movement soon became influential in many spheres of human activity, especially in the arts. The emphasis on national differences was for a time minimized, and the brotherhood of all humanity became an ideal. In music, nationalistic style elements began to lose their appeal, and the use of universal elements eventually resulted in a style that became somewhat general in all parts of musical Europe. To the degree that the common man (that is, the man who belonged to neither the nobility nor the clergy) became aware of cultural matters, 
he became a supporter of the arts. Public concerts arose, and the new music began to reflect his interests and cater to his taste, thus avoiding complications of structure and texture. In short, much music of the time became simpler through minimal use of counterpoint, became an object of pleasure and entertainment that made no great demands on the listener. The distinction between secular and sacred styles, which had greatly lessened in the Baroque period, tended to virtually disappear, and the expressiveness of a piece of vocal music did not depend on the nature of the text to which it was set. ${ }^{2}$

\section{Defining the scope of this study}

The purpose of this document is to provide a bibliography of the Roman Catholic Ordinary Masses from circa 1750 to circa 1820 to support conductors and students of choral music in their research about masses. Initially, the project was to have included a list of masses for each composer and their bibliography. This premise became impractical for two major reasons due to limitations of resources: 1 . Most of the lesser-known composers do not have their masses published; thus, a list of their works would not be useful for the intention of this work, since its purpose is to provide readily useful materials. 2. Some of the lesser-known composers whose works are published have not yet been researched, so academic documentation is not available for the bibliographic purpose. Therefore, the core of the document will provide a list of masses and bibliography of the most popular composers: Johann Michael Haydn, Franz Joseph Haydn, Wolfgang Amadeus Mozart, Ludwig van Beethoven, and Franz Schubert.

The first chapter provides a comprehensive bibliography about the genre, the style, and the political and religious conditions of the time. Writings on these topics are numerous, and it seemed advantageous to offer less explanation and more data on resources, thus avoiding repetition. The first chapter also includes several tables with lists of composers and their number

\footnotetext{
${ }^{2}$ Ulrich, Homer. A Survey of Choral Music. (New York: Harcourt Brace Jovanovich, Inc., 1973), 117.
} 
of masses, and a list of lesser-known composers whose works are unpublished but had been employed as church musicians, thus likely had been involved in the composition of masses. This document will provide to conductors and choral students useful resources on the masses of the eighteenth century, as well as encourage conductors to include these compositions in performance programs. 


\section{The mass compositions from circa 1750 to 1820}

The late eighteenth-century orchestral setting of the Mass Ordinary cultivated by Haydn, Mozart, and their Austro-German contemporaries is one of the more impressive and appealing genres in the musical heritage of the church, but arguably one of the most challenging and misunderstood in the modern practice. Due largely to its association with some of history's most widely revered composers, it holds a fair degree of both academic and popular interest. ${ }^{3}$

The concerted mass is a representation of the choral tradition during the eighteenth century. Several authors of choral music documents identify Austrian composers as the most prolific in terms of Catholic mass composition during the Classical Period. Franz Joseph Haydn and Wolfgang Amadeus Mozart are the most well-known composers of the genre when considering the printed editions of their works, as well as the number of studies related to their masses. In several books of choral literature, in the sections about masses, Michael Haydn stands with F.J. Haydn and Mozart due to his contribution to the mass genre. Even though he is not widely known these days, he was a composer of relevance during his lifetime. Franz Schubert, a transitional composer from the 18th-century classical style to the 19th-century romantic style, also receives regular attention from book writers as his choral music, according to authors such as Dennis Shrock, still lies in the realm of the classical style. Beethoven has composed only two masses but both of them have been widely studied and performed; his missa solemnis is one of the most well-known masses from the period.

The above-mentioned composers and their choral masses have been widely studied. However, many more composers were writing Roman Catholic Ordinary Masses in the period of the Enlightenment. Bruce MacIntyre cataloged 28 composers and 72 masses that represent the

\footnotetext{
${ }^{3}$ Arenas, Erick. 2014. "Beyond the 'Viennese Mass': Thoughts on the History, Use and Modern Understanding of the Eighteenth-Century Austro-German Orchestral Mass Repertoire.” Sacred Music 141 (4): 21, http://search.ebscohost.com.www.libproxy.wvu.edu/login.aspx?direct=true \&db=mah\&AN=110663990
} 
works and the people that played an essential role in the composition of the concerted mas ses in Vienna from 1741 to 1783.

This small sample provides a spectrum of how many composers may have worked for churches during the entire classical period. Vienna was a center of the Catholic tradition. Thus, probably the numbers of composers were higher than in other cities and countries. However, composers that are not known today must have been active in other European countries such as France and Italy. These, as well as some European colonies, followed the Catholic traditions.

Composers such as those in MacIntyre's list have received limited attention and research. Only a few of them have other recorded documentation other than MacIntyre's dissertation. One reason for this lack of study could be that many masses have not been published. As observed in the examined documents (e.g., dissertations, articles, books) the works only exist in a few manuscripts, which prevented a broader circulation and conservation.

Another reason could have been a similar situation to that of Michael Haydn. He was a great composer of masses but not as prolific in other genres of music; thus, he did not become appreciated by a larger audience during his lifetime. Although he was an influential composer of church music, performance of sacred compositions would usually remain limited to the church where they were composed, as sacred music was not used as concert music as it was in the following centuries. The best scenario for a composer of sacred music was to have his compositions performed in other churches. The table 1.1 includes composers from Austria and Germany, including the list of lesser-known composers explored in MacIntyre's dissertation. The information contained in the table includes their birth and death dates and the number of masses they composed. The tables that follow do not represent a comprehensive list of composers, rather 
it is a sample of how many more composers existed whose music has not been widely explored or has been lost.

Table 1.1 German and Austrian Composers

\begin{tabular}{|l|l|l|}
\hline Name & Dates & Approximate Number of Masses \\
\hline Adlgasser, Anton Cajetan & $1729-1777$ & 4 \\
\hline Albrechtsberger, Johann Georg & $1736-1809$ & 30 \\
\hline Arbesser, [Franz Paul] ${ }^{4}$ Ferdinand & $1719-1794$ & 4 \\
\hline Bonno, Giuseppe & $1711-1788$ & 30 \\
\hline Boog, Johann Nepomuk & $1724-1764$ & 16 \\
\hline Carl, Anton & $1717-1784$ & 22 \\
\hline Dittersdorf, Karl Ditters von & $1739-1799$ & 12 \\
\hline Eberlin, Johann Ernst & $1702-1762$ & 58 \\
\hline Eybler, Joseph Leopold & $1765-1846$ & 33 \\
\hline Friberth, [Franz] Karl & $1736-1816$ & 9 \\
\hline Gassman, Florian Leopold & $1729-1774$ & 5 \\
\hline Grassl ${ }^{5}$ & & 14 \\
\hline Gsur, Tobias & $1725-1794$ & 7 \\
\hline Hasse, Johann Adolf & $1699-1783$ & 15 \\
\hline Haydn, Franz Joseph & $1732-1809$ & 13 \\
\hline Haydn, Johann Michael & $1737-1806$ & 33 \\
\hline Hofmann, Leopold & $1738-1793$ & 33 \\
\hline Holler, Georg Augustin & $1744-1814$ & 1 \\
\hline & & \\
\hline
\end{tabular}

\footnotetext{
${ }^{4}$ The square brackets are used in the original resource and mean that there are variations on those names.

5 There were at least two composers called Grassl. MacIntyre, Bruce Campbell. "The Viennese Concerted Mass of the Early Classic Period: History, Analysis, and Thematic Catalogue." (Ph.D diss., The City University of New York, New York, 1984), 188-191. ProQuest Dissertations \& Theses Global.
} 


\begin{tabular}{|l|l|l|}
\hline Holzbauer, Ignaz & $1711-1783$ & 36 \\
\hline Hummel, Johann Nepomuk & $1778-1837$ & 5 \\
\hline Kohaut, Carl von & $1726-1784$ & 8 \\
\hline Krottendorfer, [Johann Baptist] Joseph & $1741-1798$ & 10 \\
\hline Martínez, Marianne von ${ }^{6}$ & $1744-1812$ & 4 \\
\hline Monn, Mathias Georg & $1717-1750$ & 6 \\
\hline Mozart, Leopold & $1719-1787$ & 3 \\
\hline Mozart, Wolfgang Amadeus & $1756-1791$ & 17 \\
\hline Naumann, Johann Gottlieb & $1741-1801$ & 1 \\
\hline Müller, Franz Silverius & $1754-1812$ & 2 \\
\hline Reuter Jr., [Johann] Georg von & $1708-1772$ & 72 \\
\hline Schmidt, Ferdinand & $1693 / 94-1756$ & 14 \\
\hline Schubert, Franz & $1797-1828$ & 6 \\
\hline Schiedermayer, Johann Baptist & $1779-1840$ & 1 \\
\hline Seuche, Joseph [Franz] & $1701 / 02-1790$ & 19 \\
\hline Sonnleithner, Christoph & $1734-1786$ & 14 \\
\hline Strasser ${ }^{7}$ & & 17 \\
\hline Tuma, Franz & $1704-1774$ & 65 \\
\hline Vanhal, Jan Krtitel [Johann Baptist] & $1739-1813$ & 60 \\
\hline Wagenseil, Georg & $1715-1777$ & 17 \\
\hline Ziegler, Joseph Paul & $1722-1767$ & 6 \\
\hline & & 6 \\
\hline
\end{tabular}

\footnotetext{
${ }^{6}$ One of the first women composers in Vienna. MacIntyre, Bruce Campbell. "The Viennese Concerted Mass of the Early Classic Period: History, Analysis, and Thematic Catalogue.” (Ph.D diss., The City University of New York, New York, 1984), 212-217. ProQuest Dissertations \& Theses Global.

${ }^{7}$ There were several composers called Strasser. MacIntyre, Bruce Campbell. "The Viennese Concerted Mass of the Early Classic Period: History, Analysis, and Thematic Catalogue." (Ph.D diss., The City University of New York, New York, 1984), 234-237. ProQuest Dissertations \& Theses Global.
} 
In books of choral history and choral literature such as A History of Western Choral

Music by Chester Alwes, the sections dedicated to more detailed information about masses in the classical period include no more than Michael Haydn, Joseph Haydn, W. A. Mozart, Beethoven, and Schubert. Holmer Ulrich in A Survey of Choral Music does include Luigi Cherubini as a representation of the Italian composers, even though he is a later composer than the abovementioned five. According to Shrock, even though France and Italy were Catholic countries during the classical period,

Sacred music did not, however, capture the creative imaginations of Italian and French Classical-era composers, whose main interest were in opera and purely instrumental forms... Sacred music also did not have the widespread support of clerical administrators, who continued to be interested in works of the Renaissance and Baroque eras... The Ordinary [Mass] settings were typically scored for soloists and chorus, with instrumental accompaniment of winds in pairs, trumpets, timpani and strings. ${ }^{8}$

There are composers from Italy and France that did compose masses, however, there are limited resources about Italian and French mass settings in the classical period.

The table 1.2 provides a list of composers found in an aleatory manner (e.g., Wikipedia, publishers catalog, composers that were discovered while reading the documents concerning this research, etc.). The biographies of such composers include records about the approximate number of masses each composer wrote. Composers that died long after 1820 that are included in this list have been considered, in history books, as composing in the classical style, at least when it concerns their choral compositions.

\footnotetext{
${ }^{8}$ Shrock, Dennis. Choral Repertoire. (New York: Oxford University Press, 2009), 388.
} 
Table 1.2. Italian and French Composers

\begin{tabular}{|l|l|l|}
\hline Name & Dates & Approximate number of masses \\
\hline Cafaro, Pasquale & $1706-1787$ & 1 \\
\hline Cambini, Giuseppe & $1746-1810 / 46 ?$ & 5 \\
\hline Casali, Giovanni Battista & $1715-1792$ & 2 \\
\hline Casciolini, Claudio & $1697-1760$ & 1 \\
\hline Cherubini, Luigi & $1760-1842$ & 10 \\
\hline Cimarosa, Domenico & $1749-1801$ & 10 \\
\hline Farinelli, Giuseppe & $1769-1836$ & 5 \\
\hline Galuppi, Baldassare & $1706-1785$ & 52 \\
\hline Gatti, Luigi & $1740-1817$ & 1 \\
\hline Gossec, François-Joseph & $1734-1829$ & 1 \\
\hline Jommelli, Niccolo & $1714-1774$ & 1 \\
\hline Paisiello, Giovanni & $1740-1816$ & 9 \\
\hline Pavona, Pietro Alessandro & $1728-1786$ & 1 \\
\hline Platti, Giovanni Benedetto & $16979-1763$ & 4 \\
\hline Predieri, Luca Antonio & $1688-1767$ & 14 \\
\hline Righini, Vincenzo & $1756-1812$ & 1 \\
\hline Sacchini, Antonio & $1730-1786$ & 2 \\
\hline Salieri, Antonio & $1750-1825$ & 5 \\
\hline Touchemoulin, Joseph & $1727-1801$ & 1 \\
\hline Zingarelli, Niccolo Antonio & $1752-1873$ & 28 \\
\hline
\end{tabular}

Other composers from Italy were employed in church positions, but there is no further information about their mass compositions. They were, however, composing in a style that influenced the mass composition in Vienna, as we read in Runestad, 
Viennese church music in this period [18th century] was the product of a union of Italian and south German characteristics, and sums up many of the principal stylistic achievements of the Baroque. The Mass and other liturgical texts were set to music of a magnificent festive scale with choruses and solo ensemble sections freely intermingled, supported by full orchestral accompaniment as well as orchestral preludes and ritornellos. Especially elaborate choruses were written for the "Amen" of the Gloria and Credo in the Mass. Sequential repetitions became a common constructive device with a clearly outlined harmonic major-minor system. ${ }^{9}$

Table 1.3. Lesser-known Italian Composers who were employed in churches.

\begin{tabular}{|l|l|}
\hline Name & Dates \\
\hline Anfossi, Pasquale & $1727-1797$ \\
\hline Campagnoli, Bartolomeo & $1751-1827$ \\
\hline Cirri, Giovanni Marco & $1724-1808$ \\
\hline Cocchi, Gioacchino & $1720-1804$ \\
\hline Conforto, Nicola & $1718-1793$ \\
\hline De Majo, Gian Francesco (Ciccio) & $1732-1770$ \\
\hline Fischietti, Domenico & $1725-1810$ \\
\hline Gallo, Domenico & $1730-1768$ \\
\hline Gasparini, Quirino & $1721-1778$ \\
\hline Gazzaniga, Giuseppe & $1743-1818$ \\
\hline Giordani, Giuseppe & $1751-1798$ \\
\hline Giordani, Tomasso & $1738-1806$ \\
\hline Lolli, Antonio & $1725-1802$ \\
\hline Luchesi, Andrea & $1741-1806$ \\
\hline Nardini, Pietro & $1722-1797$ \\
\hline Puganani, Gaetano & $1731-1798$ \\
\hline
\end{tabular}

${ }^{9}$ Donald Grout, A History of Western Music (New York: W. W. Norton \& Co., 1960), p. 328. In Runestad, Cornell Jesse. "The Masses of Joseph Haydn: A Stylistic Study." DMA diss., University of Illinois at Urbana-Champaign, Urbana, 1970. ProQuest Dissertations \& Theses Global. 


\begin{tabular}{|l|l|}
\hline Rutini, Giovanni Marco & $1724-1808$ \\
\hline Sammartini, Giovanni Battista & $1700-1775$ \\
\hline Tozzi, Antonio & $1736-1812$ \\
\hline
\end{tabular}

During the Enlightenment, music for the Roman Catholic Church had been making good progress. The church was strong in the South of Europe and in these regions the rise of the opera and orchestra was also vigorous. The masters of opera and orchestra composition were also masters of the music for the church. Thus the new classic forms of classic music were introduced into the music of the Roman Catholic church. The entire mass was now seen as a classic art form. ${ }^{10}$

The music of the Catholic Church was mainly a cappella and polyphonic, following the traditions of Palestrina. Since the 17th century, instruments have been added to the compositions and, in the classical period,

The compositional and stylistic models of church music established in the 17th century persisted, intensifying the tension between the churchly stile antico and the fascinating 'light airs and turbulent accompaniments'(Charles Burney) imported from Italian opera complemented later in the century by new formal techniques derived from symphonic music. ${ }^{11}$

The referred style that was developed during the 17th century is the "concerted" style. Also from the Grove Music Online:

Both the Ordinary of the Mass and psalm texts were divided into sections and treated either as a series of concertante, homophonic or stile antico choruses, solos or duets set according to the prevailing operatic norms, or as concerto-like combinations of soloists and chorus. The orchestra (mainly strings in Italy but more varied in German-speaking lands) or continuo maintained a constant rhythmic flow animated by motivic repetition. Words were repeated many times over to fill out the demands of the musical form. By the end of the century

\footnotetext{
${ }^{10}$ Squire, Russel N. "Music in the Reformation.” In Church Music, 112-171. (1962. Reprint, St. Louis: The Bethany Press, 1968), 153.

${ }^{11}$ Dyer, Joseph. "Roman Catholic church music." Grove Music Online. 2001. Accessed 5 Jun. 2020. https://wwwoxfordmusiconline-com.www.libproxy.wvu.edu/grovemusic/view/10.1093/gmo/9781561592630.001.0001/omo$\underline{9781561592630-\mathrm{e}-0000046758 .}$
} 
instrumental ritornellos and independent sinfonias had become integral components of the large-scale sacred concerto. ${ }^{12}$

The masses were divided into forms or types. The most recurrent in the present catalog are the Missa Brevis and the Missa Solemnis. There are, however, a wider variety of labels and discrepancies of definitions. The quotations that follow explain a few of the terms in these categories and might help to clarify the types of masses in different manners. In MacIntyre, we read,

An 1857 catalogue for Vienna's Schottenstift lists Masses according to three categories: "vokal" (probably a cappella), "de Dominica" (ordinary Sundays), and "solemnis" (special feasts).15 In sum, then, Masses in contemporary catalogues were classified and arranged differently from place to place, undoubtedly according to the circumstances and needs of the local choir director or institution. ${ }^{13}$

According to Runestad,

The Viennese classical mass divides into four groups according to the character and function of the instrumental accompaniment:

1. Long Masses (Missae Solemnes) with a predominately instrumental attitude, whose festive character is emphasized through use of timpani and trumpets.

2. Masses whose instrumental accompaniment includes obbligato instruments or concertante organ.

3. Masses where instruments simply double the chorus "colla parte," with soli accompanied by continuo.

4. Masses with independent accompaniment throughout but without obbligato instruments. ${ }^{14}$

\footnotetext{
${ }^{12}$ Same as footnote 9.

${ }^{13}$ MacIntyre, Bruce Campbell. "The Viennese Concerted Mass of the Early Classic Period: History, Analysis, and Thematic Catalogue.” (Ph.D diss., The City University of New York, New York, 1984), 10. ProQuest Dissertations \& Theses Global.

${ }^{14}$ Walter Senn, "Messe" in Musik in Geschichte und Gegenwart, Vol. IX (Kassel: Barenreiter, 1961), col. 201. In Runestad, Cornell Jesse. "The Masses of Joseph Haydn: A Stylistic Study.” DMA diss., University of Illinois at Urbana-Champaign, Urbana, 1970. ProQuest Dissertations \& Theses Global.
} 
In Alwes,

Differences in style and chronology suggest that Haydn experimented with the various types of Mass composition currently in fashion, including Masses in both the stile antico and the more modern, symphonic style. Choosing the latter path led to a choice of three formats:

1. Missa solemnis: a large Mass for vocal soloist, chorus, and full orchestra.

2. Missa brevis: a "short" Mass, the brevity of which was attained by the avoidance of word repetition, extended contrapunctual sections, and aria structures, or by the extreme measure of "textual telescoping" (i.e., presenting different text simultaneously in each choral voice), or

3. Cantata Mass: An Italian type of Missa solemnis in which the texts (especially the Gloria and Credo) were subdivided to form movements that allowed variation in key, meter, texture, orchestration, and tempo. ${ }^{15}$

Although the bibliographic literature concerning choral music in the classical period is not as abundant as the materials from other periods, there is still a lot that can be learned about the masses from other documents about the classical period even though they are not specific to choral music. The study of the works listed in the bibliography that follows provides the reader with an extensive understanding of the mass genre and sacred music during the classical period, including the leading composers, and topics that complement the studies of the Roman Catholic Ordinary Mass from circa 1750 to circa 1820.

${ }^{15}$ Alwes, Chester L. A History of Western Choral Music. (New York: Oxford University Press, 2015), 336. 


\section{Bibliography}

\section{Books:}

Alwes, Chester L. A History of Western Choral Music. New York: Oxford University Press, 2015.

Blume, Friedrich. Classic and Romantic Music: A Comprehensive Survey. Translated by M. D. Herter Norton. New York: W.W. Norton, 1970.

Downs, Philip G. Classical Music: The Era of Haydn, Mozart, and Beethoven. The Norton Introduction to Music History. New York: W.W. Norton, 1992.

Eisen, Cliff, and Alan Davison, eds. Late Eighteenth-Century Music and Visual Culture. Music and Visual Cultures, Volume 1. Turnhout, Belgium: Brepols, 2017.

Heartz, Daniel. Mozart, Haydn and Early Beethoven, 1781-1802. 1st ed. New York: W.W. Norton, 2009.

Pauly, Reinhard G. Music in the Classic Period. 4th ed. Prentice-Hall History of Music Series. Upper Saddle River, N.J.: Prentice Hall, 2000.

Pestelli, Giorgio. The Age of Mozart and Beethoven. Cambridgeshire: Cambridge University Press, 1984.

Ratner, Leonard. Classic Music: Expression, Form, and Style. New York: Schirmer Books, 1980.

Rosen, Charles. The Classical Style. 1971. Rev. ed. New York: W. W. Norton \& Company, 1988.

Sharp, Avery T., and James Michael Floyd. Choral Music: A Research and Information Guide. New York: Routledge, 2002. 
Shrock, Dennis, and James Moyer. A Conductor's Guide to Choral/Orchestral Repertoire. Chicago: GIA Publications, 2017.

Shrock, Dennis. Choral Repertoire. New York: Oxford University Press, 2009.

Strimple, Nick. Choral Music in the Nineteenth Century. Milwaukee: Amadeus Press, 2008.

Summer, Robert J. Choral Masterworks from Bach to Britten: Reflections of a Conductor. 1941. Reprint, Maryland: Scarecrow Press, 2007.

Ulrich, Homer. A Survey of Choral Music. New York: Harcourt Brace Jovanovich, Inc., 1973.

Book Chapters:

Arnold, Denis, and John Harper. “Mass, Section III. 1600-2000.” In The New Grove Dictionary of Music and Musicians, edited by Stanley Sadie. 2nd edition. Macmillan Publishers Limited, 2001.

Barney, Katelyn, and Elizabeth Mackinlay. “The Hybrid Music Mass: a Question of Text.” In Musical Islands: Exploring Connections Between Music, Place and Research. United Kingdom: Cambridge Scholars Publisher, 2009.

Colvin, Sarah. "Musical Culture and Thought." In German Literature of the Eighteenth Century: The Enlightenment and Sensibility, edited by Becker-Cantarino Barbara, 185-221. Rochester, NY, USA; Woodbridge, Suffolk, UK: Boydell \& Brewer, 2005. Accessed June 7, 2020. doi:10.7722/j.ctt7zsv34.12.

\section{Encyclopedias, Guides, Dictionaries:}

Dyer, Joseph. "Roman Catholic church music." Grove Music Online. 2001; Accessed 5 Jun. 2020.https://www-oxfordmusiconlinecom.www.libproxy.wvu.edu/grovemusic/view/10.1093/gmo/9781561592630.001.0001/o $\underline{\text { mo-9781561592630-e-0000046758. }}$. 
Heartz, Daniel, and Bruce Alan Brown. "Classical.” Grove Music Online. 2001; Accessed 4 Jun. 2020.https://www-oxfordmusiconlinecom.www.libproxy.wvu.edu/grovemusic/view/10.1093/gmo/9781561592630.001.0001/o $\underline{\text { mo-9781561592630-e-0000005889. }}$.

McKinnon, James W., Theodor Göllner, Maricarmen Gómez, Lewis Lockwood, Andrew Kirkman, Denis Arnold, and John Harper. "Mass.” Grove Music Online. 2001; Accessed 5 Jun. 2020. https://www-oxfordmusiconlinecom.www.libproxy.wvu.edu/grovemusic/view/10.1093/gmo/9781561592630.001.0001/o mo-9781561592630-e-0000045872.

Swafford, Jan. The Vintage Guide to Classical Music. New York: Quatrain Associates, 1992.

Sadie, Stanley. The Billboard Encyclopedia of Classical Music. New York: Watson Guptill Publications, 2004.

\section{Journal Articles:}

Arenas, Erick. 2014. 'Beyond the 'Viennese Mass': Thoughts on the History, Use and Modern Understanding of the Eighteenth-Century Austro-German Orchestral Mass Repertoire.” Sacred Music 141, no. 4 (2014): 21-27. http://search.ebscohost.com.www.libproxy.wvu.edu/login.aspx?direct=true\&db=mah\&A $\underline{\mathrm{N}=110663990 .}$.

Baumol, William J., and Hilda Baumol. "On The Economics of Musical Composition in Mozart's Vienna." Journal of Cultural Economics 18, no. 3 (1994): 171-98. Accessed June 7, 2020. www.jstor.org/stable/41804887.

Beckmann-Collier, Aimee. "Sacred Choral Music in the Classical Era." The Choral Journal 31, no. 9 (1991): 5-8. Accessed June 7, 2020. www.jstor.org/stable/23548117. 
Cornelius, Jeffrey M. "The Classic Period: Accessible Repertoire For The Church Choir.” The Choral Journal 22, no. 3 (1981): 13-18. Accessed June 7, 2020. www.jstor.org/stable/23545997.

Guion, David M. "The Missing Link: The Trombone in Italy in the 17th and 18th Centuries." Early Music 34, no.2 (2006): 225-32. doi:10.1093/em/cah193.

Hogan, Richard M. “Viennese Classical Masses: Sacred or Secular?” Sacred Music 103, no. 2 (1976): 18-23.

Jones, David Wyn. “Telling Tales of Music in Vienna.” In Music in Vienna: 1700, 1800, 1900, 1-6. Woodbridge, Suffolk, UK; Rochester, Ny, USA: Boydell \& Brewer, 2016. Accessed June 12, 2020. doi:10.7722/j.ctt1d39244.5.

Mahrt, William. “Viennese Classical Masses?” Sacred Music 136, no. 4 (2009): 3-5. http://search.ebscohost.com.www.libproxy.wvu.edu/login.aspx?direct=true\&db=a9h\&A $\mathrm{N}=47692057$.

Prowse, Ronald. 2009. "The Council of Trent and the Reform of Gregorian Chant." Sacred Music 136 (3): 35-46. http://search.ebscohost.com.www.libproxy.wvu.edu/login.aspx?direct=true \&db=mah\&A $\underline{\mathrm{N}=47117096 .}$.

Raynor, Henry. "Some Reflections upon the Viennese Mass." The Musical Times 95, no. 1341 (1954): 592-96. Accessed June 7, 2020. doi:10.2307/934146.

Pauly, Reinhard G. "The Reforms of Church Music under Joseph II." The Musical Quarterly 43, no. 3 (1957): 372-82. Accessed June 14, 2020. www.jstor.org/stable/740280.

Schatkin Hettrick, Jane. 2014. "Problems in Church Music in Late Eighteenth-Century Vienna and Their Relevance for Catholic Church Musicians Today." Sacred Music 141 (4): 28- 
38.

http://search.ebscohost.com.www.libproxy.wvu.edu/login.aspx?direct=true \&db=mah\&A $\underline{N=110663991 .}$

Snyder, Robert E. "An Annotated Inventory of Easy Choral Music of the Classical Period." The Choral Journal 25, no. 9 (1985): 43-44. Accessed June 12, 2020. www.jstor.org/stable/23546841.

\section{Theses and Dissertations:}

Chen, Jen-Yen. "The Tradition and Ideal of the Stile Antico in Viennese Sacred Music, 17401800.” Ph.D. diss., Harvard University, Cambridge, 2000. ProQuest Dissertations and Theses Global.

Bernarducci, Anthony. "A Historical and Analytical Survey of the Missa Brevis Genre from 1490 to Modern Times.” Ph.D. diss., The Florida State University, Tallahassee, 2015. ProQuest Dissertations \& Theses Global.

Kirkwood, Jonathan. "Haydn, Mozart and Beethoven: The Artist as Prophet. Music as Language, Communication and Ideology.” M.A. thesis, California State University, Dominguez Hills, 2005. ProQuest Dissertations \& Theses Global.

MacIntyre, Bruce Campbell. “The Viennese Concerted Mass of the Early Classic Period: History, Analysis, and Thematic Catalogue.” Ph.D diss., The City University of New York, New York, 1984. ProQuest Dissertations \& Theses Global.

Maitland, Alison I. "The Development of Form and Style in Eighteenth Century Salzburg Church Music." Ph.D. diss., University of Aberdeen, United Kingdom, 1972. ProQuest Dissertations \& Theses Global. 
Manson, David Ross. "Trombone Obbligatos with Voice in the Austrian Sacred Music of the Seventeenth and Eighteenth Centuries: Representative Excerpts with Historical Introduction and Commentary.” D.M.A. diss., University of Cincinnati, Cincinnati, 1997. ProQuest Dissertations and Theses Global.

Renton, Barbara Ann. “The Musical Culture of Eighteenth Century Bohemia, with Special Emphasis on the Music Inventories of Osek and the Knights of the Cross.” Ph.D. diss., City University of New York, New York City, 1990. ProQuest Dissertations and Theses Global.

Windt, Nathan. “A Conductor's Guide to Selected Short, Pre-Viennese Liturgical and Sacred Choral Works of Wolfgang Amadeus Mozart.” D.M.A. diss., University of Cincinnati, Cincinnati, 2008. ProQuest Dissertations and Theses Global.

\section{Periodicals:}

Hogan, Richard. 1976. "Viennese Classical Masses: Sacred or Secular?” Sacred Music 103, n. 2 (1976): 18-23.

http://search.ebscohost.com.www.libproxy.wvu.edu/login.aspx?direct=true \&db=rih\&AN $=\mathrm{A} 611069$. 


\section{The Catalog}

The purpose of this catalog is to provide the choral conductor with a practical resource to study the masses from circa 1750 to circa 1820 . The catalog is intended to reach the Englishspeaking population especially American choral directors in academia. For this reason, the bibliography included in this catalog is limited to documents in the English language that are mostly accessible online. Searching for materials can sometimes be an obstacle while preparing classes or scores for rehearsals. This document could serve as a resource for academic classes such as choral literature as well as a resource for basic research on the topic. Additionally, those willing to dive into musicology studies will find in this resource a starting point.

The search was made predominantly through the following databases: Music Index, EbscoHost, Academic Search Complete, ProQuest Dissertations and Theses Global, JSTOR, Google, Google Books, Wikipedia, IMSLP, and Music Publishers Websites. Some documents were found in the bibliographies provided in the selected dissertations. Reviews of recordings are not included as they are too numerous and have varying degrees of usefulness.

The reader will find some particularities in several aspects of the catalog. First, there will be some information in between the square brackets []. If the square brackets are in the middle of a quotation, it means that a word was added to complete the sense of the phrase. If the square brackets are around information in the catalog list, such as a name, a city, a date, or a number, this means that the information is available but it is not conclusive. Further research might reveal updated data. If a question mark is in between the square brackets, that is because the information was not found during the research for this document.

There are some characteristics of the orchestration worthy to be highlighted in case the reader doesn't get the chance to explore the specific documents that contain these pieces of 
information. The first point is that most of the masses did not include the instrument viola, even

though the viola was an instrument already present in the repertoire since the late 17th century.

According to Runestad,

At the beginning of the eighteenth century, the strings comprised the only standardized portion of the orchestra. Lower viols had been replaced by violas and cellos in the latter part of the seventeenth century. The infrequent use of violas, especially at Salzburg, during this time is puzzling. Since they do appear occasionally, one cannot accept the claim that they were excluded as being secular. And since they were used in Austria before the middle of the century, one is tempted to regard their omission at Salzburg as a case of local preference, for the ample resources of the Archbishop's chapel would surely have been able to provide them. Einstein, while admitting that no firm answer has been found, conjectures that violas probably were used, but only to double the bass part an octave higher. This supposition, if true, accounts for the fact that we have few written out viola parts. If an independent viola part is present, it usually doubles the bass or supplies a harmonic inner voice, largely following the bass rhythm. It is always simple, employs few double stops, and no work in high positions.

Rosters of Salzburg musicians contain no violists; that instrument, when required, must have been played by another string player. The general simplicity and lack of interest in viola parts of eighteenth-century music suggests that it was an instrument played by musicians of very modest attainment. ${ }^{16}$

The information about the absence of the violas requires a point of explanation regarding the "church trio." The reader will see that most of the compositions will have 2 violins, bass, and organ. This grouping of instruments is called the church trio and was the base for most of the compositions since it was the most common group of instruments available. It doesn't mean that other instruments could not be added, rather that this was the basic structure of the orchestration.

Runestad also pointed out the manner in which trumpets were being designated:

Trumpet parts, although still labelled clarino, began to lose their high florid character and assume lower ranges, characteristic rhythmic patterns, and a generally harmonic rather than melodic function. During the eighteenth century there is some ambiguity in the use of the terms trombe and clarini. Sometimes composers differentiated between the two by designating clarini for high, florid,

\footnotetext{
${ }^{16}$ Runestad, Cornell Jesse. "The Masses of Joseph Haydn: A Stylistic Study." (DMA diss., University of Illinois at Urbana-Champaign, Urbana, 1970),11-12, ProQuest Dissertations \& Theses Global.
} 
melodic writing, and trombe for mainly rhythmic and harmonic punctuations in the classic manner. Occasionally both clarini and trombe are indicated. ${ }^{17}$

In his dissertation, Runestad provides a detailed description of the style of the masses of the 18th century. His dissertation title specifies that the masses of Joseph Haydn are the study topic, but according to the author, he explores the mass as a genre before approaching the specificities of Haydn's masses. It is a crucial source for the conductor seeking to understand several core aspects of the masses of this period. More similar resources are available in the bibliography in the first chapter.

In the following catalog, the reader will find many bibliographic titles about specific masses or groups of masses for the given composers. There are works that have not yet been largely explored and that might serve as a topic for further research. The composers will be listed in chronological order of birth. The final list will include a bibliography for the composers that have received some study but less than the better-known composers.

\footnotetext{
${ }^{17}$ Runestad, Cornell Jesse. "The Masses of Joseph Haydn: A Stylistic Study." (DMA diss., University of Illinois at Urbana-Champaign, Urbana, 1970), 12, ProQuest Dissertations \& Theses Global.
} 


\section{Franz Joseph Haydn (1732 - 1809)}

Although Haydn spent most of his life working for Esterházy’s princes, his compositional style did not lack variety. In his first compositional period, Haydn composed six masses (besides two previous masses of which the authorship is questionable). These masses were in the style of the masses composed in Vienna by composers such as his brother Michael Haydn and Mozart, amongst other predecessors and contemporary fellows, mainly following the rules and interest of the archbishops. In the second period of mass composition, after his trip to London, his masses changed considerably and were labeled as symphonic masses especially due to the instrumentation - e.g., the novel inclusion of flutes and clarinets. Haydn's late masses contributed greatly to the transition of compositional style from the 18 th to the 19 th century. ${ }^{18}$ According to Demaree and Moses,

The Masses of Joseph Haydn are his new formulation of an historic Viennese genre, separate from his operas and his instrumental works, and they need to be studied, heard, and performed as such. It is helpful to know all Haydn's forms, but no one of them needs to serve as the Arc de Triomphe. The real identity of his style lives in the body of common principles underlying all these genres. These principles became the "Viennese Classical Style," as Haydn shaped it. ${ }^{19}$

\footnotetext{
${ }^{18}$ Nineteenth-century choral music properly begins in 1796 with the composition and performance of the first two of the last great Masses of Franz Joseph Haydn, works that would have a profound impact on virtually all later music. These masses not only established a more or less standard duration for such works but also introduced symphonic formal structures and an innovative approach to tonality, both of which helped to transplant the Mass and the other liturgical forms directly into the realm of concert music. Strimple, Nick. Choral Music in the Nineteenth Century. (Milwaukee: Amadeus Press, 2008), 01.

${ }^{19}$ Demaree, Robert W., and Don V. Moses The Masses of Joseph Haydn. (Frankfort: Classical Heritage, 2008), 97.
} 


\section{Bibliography}

\section{Books:}

Alwes, Chester L. “The Mass (1750-1900).” In A History of Western Choral Music, 334-369. New York: Oxford University Press, 2015.

Demaree, Robert W., and Don V. Moses. The Masses of Joseph Haydn. Frankfort: Classical Heritage, 2008.

Landon, H.C. Robbins. "Haydn in England: 1791-1795." Vol. 3 of Haydn: The Chronicle and Works. 1st American ed. Bloomington: Indiana University Press, 1976.

International Haydn Conference (1975: Washington, D.C.), Jens Peter Larsen, Howard Serwer, James Webster, and American Musicological Society. Haydn Studies: Proceedings of the International Haydn Conference, Washington, D.c., 1975. 1st ed. New York: W.W. Norton, 1981.

Strimple, Nick. "Austria and Germany”. In Choral Music in the Nineteenth Century, 11-80. Milwaukee: Amadeus Press, 2008.

\section{E-books:}

Sutcliffe, W. Dean, ed. Haydn Studies. Cambridge: Cambridge University Press, 1998. Accessed July 6, 2020. ProQuest Ebook Central.

\section{Journal Articles:}

Johnson, Eric A. “Franz Joseph Haydn's Late Masses: An Examination of the Symphonic Mass Form.” The Choral Journal 42, no. 7 (2002): 19-24. Accessed July 6, 2020. www.jstor.org/stable/23554367. 
Demaree, Robert W., and Don V. Moses. “A New View of Haydn: A Twenty-first Century Reassessment of the Masses of Joseph Haydn.” The Choral Journal 50, no. 2 (2009): 3851. Accessed June 14, 2020. www.jstor.org/stable/23560195.

Geiringer, Karl. “The Small Sacred Works by Haydn in the Esterhazy Archives at Eisenstadt.” The Musical Quarterly 45, no. 4 (1959): 460-72. Accessed June 14, 2020. www.jstor.org/stable/740596.

Green, Edward. "The Principle of Chromatic Saturation in the Late Choral Music of Mozart and Haydn.” The Choral Journal 46, no. 12 (2006): 34-50. Accessed June 12, 2020. www.jstor.org/stable/23556460

Groves, Stephen. “Haydn Vocal Works, Canonic and Obscure.” Early Music 39, no. 3 (2011): 466-69. Accessed June 14, 2020. www.jstor.org/stable/41262239.

Holmes, E. "Haydn's Masses.” The Musical Times and Singing Class Circular 7, no. 150 (1855): 83-85. Accessed July 6, 2020. doi:10.2307/3370008.

Holmes, E. “Haydn's Masses. No. I (Continued)." The Musical Times and Singing Class Circular 7, no. 151 (1855): 99-102. Accessed July 6, 2020. doi:10.2307/3370635. Holmes, E. “Haydn's Masses. No. II (Continued).” The Musical Times and Singing Class Circular 7, no. 152 (1855): 115-25. Accessed July 6, 2020. doi:10.2307/3369977. Holmes, E. “Haydn's Masses. No. III (Continued).” The Musical Times and Singing Class Circular 7, no. 153 (1855): 131-40. Accessed July 6, 2020. doi:10.2307/3370612. Holmes, E. “Haydn's Masses. No. IV (Continued)." The Musical Times and Singing Class Circular 7, no. 155 (1856): 163-65. Accessed July 6, 2020. doi:10.2307/3370860. Holmes, E. "Haydn's Masses. No. IV (Continued)." The Musical Times and Singing Class Circular 7, no. 156 (1856): 179-80. Accessed July 6, 2020. doi:10.2307/3370426. 
Holmes, E. "Haydn’s Masses. No. V (Continued).” The Musical Times and Singing Class Circular 7, no. 157 (1856): 195-98. Accessed July 6, 2020. doi:10.2307/3370056. Holmes, E. “Haydn's Masses. No. VI (Continued)." The Musical Times and Singing Class Circular 7, no. 158 (1856): 211-13. Accessed July 6, 2020. doi:10.2307/3370310. Holmes, E. “Haydn's Masses. No. VII (Continued)." The Musical Times and Singing Class Circular 7, no. 164 (1856): 307-09. Accessed July 6, 2020. doi:10.2307/3369929. Holmes, E. "Haydn”s Masses. No. VII (Continued)." The Musical Times and Singing Class Circular 8, no. 170 (1857): 21-23. Accessed July 6, 2020. doi:10.2307/3370477.

Holmes, E. “Haydn’s Masses. Nos. VIII., IX (Continued).” The Musical Times and Singing Class Circular 7, no. 167 (1857): 365-68. Accessed July 6, 2020. doi:10.2307/3370459.

Holmes, E. "Haydn's Masses. Nos. X., XI (Continued).” The Musical Times and Singing Class Circular 8, no. 177 (1857): 135-38. Accessed July 6, 2020. doi:10.2307/3370945.

Holmes, E. “Haydn's Masses. No. XII." The Musical Times and Singing Class Circular 8, no. 186 (1858): 283-85. Accessed July 6, 2020. doi:10.2307/3370273.

Holmes, E. “Haydn's Masses. Nos. XIII. \& XIV.” The Musical Times and Singing Class Circular 8, no. 188 (1858): 315-16. Accessed July 6, 2020. doi:10.2307/3370017. Hughes, Rosemary. “The Haydn Orchestra.” The Musical Times 93, no. 1313 (1952): 299-301. Accessed June 14, 2020. doi:10.2307/935198.

Johnson, Eric A. “Franz Joseph Haydn's Late Masses: An Examination of the Symphonic Mass Form.” The Choral Journal 42, no. 7 (2002): 19-24. Accessed June 14, 2020. www.jstor.org/stable/23554367. 
Jones, David Wyn. “Becoming a Complete Kapellmeister: Haydn and Mattheson’s “Der Vollkommene Capellmeister"." Studia Musicologica 51, no. 1/2 (2010): 29-40. Accessed June 14, 2020. www.jstor.org/stable/25746238.

Lamkin, Kathleen. "Haydn’s Musicians at the Esterházy Court, 1796 - 1802.” The Choral Journal 50, no. 2 (2009): 24-37. Accessed June 14, 2020. www.jstor.org/stable/23560193.

Martin, Sherrill V. “The Esterházys: Hungary’s Noble Patrons of Music.” American Music Teacher 32, no. 6 (1983): 12-16. Accessed June 14, 2020. www.jstor.org/stable/43541637.

Papanikolaou, Eftychia. "Between Tradition and Innovation: Sacred Intersections and the Symphonic Impulse in Haydn's Late Masses.” Sacred Music 136, no. 4 (2009): 6-16. http://search.ebscohost.com.www.libproxy.wvu.edu/login.aspx?direct=true $\& d b=m a h \& A$ $\underline{\mathrm{N}=47692058 .}$.

Zaslaw, Neal. "Mozart, Haydn and the Sinfonia Da Chiesa.” The Journal of Musicology 1, no. 1 (1982): 95-124. Accessed June 14, 2020. doi:10.2307/763639.

Webster, James. “The Creation, Haydn's Late Vocal Music, and the Musical Sublime.” In Haydn and His World, edited by Sisman Elaine, 57-102. Princeton, New Jersey: Princeton University Press, 1997. Accessed June 14, 2020. doi:10.2307/j.ctt7rqdr.5.

\section{Theses and Dissertations:}

Gibbs, Thomas Jordan, Jr. “A Study of Form in the Late Masses of Joseph Haydn.” PhD diss., The University of Texas at Austin, Austin, 1972. ProQuest Dissertations \& Theses Global. 
Eby, John Douglas. “Two Masses Attributed to Haydn from the University Library, Warsaw: An Edition and Commentary.” M.A. diss., The University of Western Ontario, London (Canada), 1978. ProQuest Dissertations and Theses Global.

Ferrantelli, Salvatore John. “Joseph Haydn’s Missae Breves: A Conductor’s Analysis.” D.Mus. diss., Indiana University, Bloomington, 1983.

Nafziger, Kenneth James. "The Masses of Haydn and Schubert: A Study in the Rise of Romanticism.” DMA diss., University of Oregon, Oregon 1970. ProQuest Dissertations \& Theses Global.

Pedersen, Keith Ernest. “The sonata/fugue in Haydn's Sacred Choral Music.” D.M.A. diss., University of Illinois at Urbana-Champaign, Urbana 1997. ProQuest Dissertations \& Theses Global.

Runestad, Cornell Jesse. "The Masses of Joseph Haydn: A Stylistic Study.” DMA diss., University of Illinois at Urbana-Champaign, Urbana, 1970. ProQuest Dissertations \& Theses Global.

Trott, Donald Lee. "Patterns of Accentuation in the Classical Style as Supported by Primary Sources and as Illustrated in the Late Masses of Franz Joseph Haydn.” D.M.A. diss., The University of Oklahoma, Norman, 1984. Ann Arbor: ProQuest. Web. 14 June 2020.

\section{Periodicals:}

“Haydn’s and Mozart’s Masses.”. Musical Magazine, or, Repository of Musical Science, Literature, \& Intelligence 1, no. 18 (1839): 284-85. http://search.ebscohost.com.www.libproxy.wvu.edu/login.aspx?direct=true $\& d b=$ mpe \&A $\underline{\mathrm{N}=45261880 .}$. 
S. E. 1839. "Haydn's and Mozart's Masses.” Musical Magazine, or, Repository of Musical

Science, Literature, \& Intelligence 1, no. 21 (1839): 330-35.

http://search.ebscohost.com.www.libproxy.wvu.edu/login.aspx?direct=true \&db=mpe\&A $\underline{\mathrm{N}=45271093}$.

\section{Reviews:}

Rayl, David. "Reviews: "the Masses of Joseph Haydn: History, Style, Performance” by Robert W. Demaree and Don V. Moses." Fontes Artis Musicae - Journal of the International Association of Music Libraries, Archives, and Documentation Centres 57, no. 4 (10, 2010): 433-435. http://www.libproxy.wvu.edu/login?url=https://search-proquestcom.www.libproxy.wvu.edu/docview/884537055?accountid=2837.

\section{Websites:}

Haydn: The Online Journal of the Haydn Society in North America.

https://www.rit.edu/affiliate/haydn/ 


\section{Hob. XXII: 5 Missa Cellensis in Honorem Beatissimae Virginis Mariae in C Major}

Eisenstadt, 1766

Scoring: SATB soloists, SATB choir, strings, continuo, organ, 2 oboes, 2 bassoons, 2 trumpets, timpani.

Editions available on IMSLP: Breitkopf \& Härtel (1811).

Publishers: Carus, Bärenreiter.

Journal Articles:

MacIntyre, Bruce C. "Music Reviews -- Messen Nr. 1-2 (Contains: Missa Brevis in F; Missa Cellensis in Honorem Beatissimae Virginis Mariae; Missa Rorate Coeli Desuper) by Joseph Haydn and Edited by James Dack and Georg Feder." Music Library Association Notes 51, no. 3 (03, 1995): 1131. http://www.libproxy.wvu.edu/login?url=https://searchproquest-com.www.libproxy.wvu.edu/docview/196741577? accountid=2837. 
Hob. XXII: 4 Missa in honorem Beatissimae Virginis Maria “Grosse Orgelsolomesse," “Missa Sancti Josephi” in E-flat Major.

Eisenstadt, 1769 (March 19)

Scoring: SATB soloist, SATB choir, strings, continuo, organ, 2 English horns, 2 bassoons, 2

trumpets, timpani.

Editions available on IMSLP: none.

Publishers: Carus, Bärenreiter. 


\section{Hob. XXII: 6 Missa Sancti Nicolai in $G$ Major.}

Eisenstadt, 1772

Scoring: SATB soloists, SATB choir, 2 oboes, 1 bassoon, 2 trumpets, timpani ${ }^{20}$, organ, continuo.

Editions available on IMSLP: Augsburg (n.d.).

Publishers: Carus, Bärenreiter.

Journal Articles:

McCaldin, Denis. "Early Haydn Mass.” The Musical Times 110, no. 1520 (1969): 1070-071. Accessed July 6, 2020. doi:10.2307/953466.

\section{Theses and Dissertations:}

Ferrantelli, Salvatore John. “Joseph Haydn’s Missae Breves: A Conductor’s Analysis.” D.Mus. diss., Indiana University, Bloomington, 1983.

${ }^{20}$ Haydn's revision in 1802 added trumpets and timpani. 


\section{Hob. XXII: 7 Missa brevis Sancti Joannis de Deo "Kleine Orgelmesse" in B-flat Major.}

Eisenstadt, circa 1775

Scoring: S soloist, SATB choir, strings, continuo, organ.

Editions Available on IMSLP: Calebe Barros (n.d.).

Publishers: Carus, Bärenreiter.

\section{Journal Articles:}

Blosser, Amy Johnston. “Senior High Choirs: Haydn’s Missa Brevis St. Johannis De Deo and Te Deum." The Choral Journal 49, no. 6 (2008): 52-55. Accessed June 14, 2020. www.jstor.org/stable/23557282

\section{Theses and Dissertations:}

Ferrantelli, Salvatore John. “Joseph Haydn’s Missae Breves: A Conductor’s Analysis.” D.Mus. diss., Indiana University, Bloomington, 1983.

Hightower, Allen Ross, III. “Franz Joseph Haydn's “Kleine Orgelmesse” (Hob. XXII:7): A Conductor's Analysis.” D.M.A. diss., University of California, Los Angeles, 2000. ProQuest Dissertations \& Theses Global. 


\section{Hob. XXII: 8 Missa Cellensis "Mariazellermesse" in C Major.}

Eisenstadt, 1782

Scoring: SATB soloist, SATB chorus, strings, continuo, organ, 2 oboes, 1 bassoon, 2 trumpets, timpani.

Editions Available on IMSLP: no full score.

Publishers: Carus, Bärenreiter.

Hob. XXII: 10 Missa Sancti Bernardi von Offida "Heiligmesse" in B-flat Major.

Eisenstadt, 1776

Scoring: SATB soloists, SATB choir, strings, 2 oboes, 2 clarinets, 2 bassoons, 2 horns, 2

trumpets, timpani, organ, continuo.

Editions Available on IMSLP: Holograph Manuscript (1796), Breitkopf \& Härtel (1801-02).

Publishers: Carus, Bärenreiter. 


\section{Hob. XXII: 9 Missa in Tempori Belli "Paukenmesse" in C Major.}

Eisenstadt, 1796

Scoring: SATB soloists, SATB choir, strings, 2 oboes, 2 clarinets, 2 bassoons, 2 horns, 2 trumpets, timpani, organ, continuo.

Editions available on IMSLP: no full score.

Publishers: Carus, Bärenreiter. 


\section{Hob. XXII: 11 Missa in Angustiis "Nelsonmesse" in D Minor.}

Eisenstadt, 1798

Scoring: SATB soloist, SATB chorus, strings, 3 trumpets, timpani, organ, continuo.

Editions Available on IMSLP: Holograph Manuscript (1798), Breitkopf \& Härtel (1803), C.F. Peters (1932), G. Henle Verlag (1965).

Publishers: Carus, Bärenreiter.

\section{Journal Articles:}

D. Millar Craig. "When Haydn Met Nelson.” The Musical Times 80, no. 1156 (1939): 416-17. Accessed June 14, 2020. doi:10.2307/921388.

Schenbeck, Lawrence. “"Missa in Angustiis” by Joseph Haydn.” The Choral Journal 25, no. 9 (1985): 19-30. Accessed June 14, 2020. www.jstor.org/stable/23546834.

\section{Theses and Dissertations:}

Bowdidge, Mark Andrew. “A Conductor's Analysis of the "Lord Nelson Mass” by Franz Joseph Haydn.” D.M.A. diss., Southwestern Baptist Theological Seminary, Fort Worth, 1998. 


\section{Hob. XXII: 12 Missa in B-flat Major “Theresienmesse”}

Eisenstadt, 1799

Scoring: Strings, 2 oboes, 2 clarinets, 1 bassoon, 2 horns, 2 trumpets, timpani, organ, continuo.

Editions Available on IMSLP: Holograph Manuscript (1799), Wiener Phillarmonischer Verlag (1924).

Publishers: Carus, Bärenreiter.

Journal Articles:

Greenlee, Robert. “Irregular Accent in Joseph-Haydn's Theresienmesse.” The Choral Journal 48, no. 10 (2008): 8-18. Accessed June 14, 2020. www.jstor.org/stable/23557684.

Hosar, Halvor K. “The Kyrie as Sonata Form: A Form-Functional Approach to Haydn's Theresienmesse." Haydn: The Online Journal of the Haydn Society in America 10, no.1 (2020). https://www.rit.edu/affiliate/haydn/kyrie-sonata-form-form-functional-approachhaydn\%E2\%80\%99s-theresienmesse

Theses and Dissertation:

Webb, Brian Patrick. “A Conductor's Analysis of Haydn”s "Theresienmesse”.” D.Mus. diss., Indiana University, Bloomington, 1977. ProQuest Dissertations and Theses Global. 
Hob. XXII: 13 Missa in B-flat Major. "Schöpfungsmesse," “Creation Mass"

Eisenstadt, 1799

Scoring: SATB solos, SATB choir, strings, 2 oboes, 2 clarinets, 2 bassoons, 2 horns, 2 trumpets, timpani, organ, continuo.

Editions Available on IMSLP: Breitkopf \& Härtel (1804).

Publishers: Carus, Bärenreiter.

Hob. XXII: 14 Missa in B-flat Major "Harmoniemesse”

Eisenstadt, 1802

Scoring: SATB soloist, SATB choir, strings, 1 flute, 2 oboes, 2 clarinets, 2 bassoons, 2 horns, 2 trumpets, timpani, organ, continuo.

Editions available on IMSLP: Holograph Manuscript.

Publishers: Carus, Bärenreiter.

Journal Articles:

Hughes, Rosemary. “Two Haydn Masses.” The Musical Times 91, no. 1288 (1950): 213-18. Accessed July 6, 2020. doi:10.2307/934861. 
Hob. XXII:1 Missa brevis “Jugendmesse”

in $F$ major

Stephansdom, c.1750 (questionable authorship)

Scoring: SS soloists, SATB choir, 2 violins, continuo, organ.

Editions Available on IMSLP: Doblinger (1955).

Publishers: Carus, Bärenreiter.

Journal Articles:

Gilbert, Nina. "Haydn's First Mass: A Practical Introduction to His Style." The Choral Journal 25, no. 9 (1985): 19-23. Accessed June 14, 2020. www.jstor.org/stable/23546833.

Greenlee, Robert. “Irregular Accent in Joseph-Haydn's Theresienmesse.” The Choral Journal 48, no. 10 (2008): 8-18. Accessed June 14, 2020. www.jstor.org/stable/23557684.

Hughes, Rosemary. “Two Haydn Masses.” The Musical Times 91, no. 1288 (1950): 213-18. Accessed July 6, 2020. doi:10.2307/934861

\section{Theses and Dissertations:}

Ferrantelli, Salvatore John. “Joseph Haydn’s Missae Breves: A Conductor’s Analysis.” D.Mus. diss., Indiana University, Bloomington, 1983. 


\section{Hob. XXII: 3 Missa Rorate Coeli Desuper in $G$ major}

Stephansdom [?] ${ }^{21}$, c. 1750 (questionable authorship)

Scoring: SATB choir, strings (2 violins), continuo, organ.

Editions Available on IMSLP: none.

Publishers: Carus, Bärenreiter.

Journal Articles:

MacIntyre, Bruce C. “Music Reviews -- Messen Nr. 1-2 (Contains: Missa Brevis in F; Missa Cellensis in Honorem Beatissimae Virginis Mariae; Missa Rorate Coeli Desuper) by Joseph Haydn and Edited by James Dack and Georg Feder." Music Library Association Notes 51, no. 3 (03, 1995): 1131. http://www.libproxy.wvu.edu/login?url=https://searchproquest-com.www.libproxy.wvu.edu/docview/196741577?accountid=2837.

\section{Theses and Dissertations:}

Ferrantelli, Salvatore John. “Joseph Haydn’s Missae Breves: A Conductor's Analysis.” D.Mus. diss., Indiana University, Bloomington, 1983.

\footnotetext{
${ }^{21}$ Location of composition is not conclusive.
} 


\section{Michael Haydn (1737-1806, Austria)}

Johann Michael Haydn (1737-1806) is one of the least known of eighteenth-century composers; he is, in fact, almost totally forgotten. His neglect is surprising, for during his lifetime Michael enjoyed considerable reknown [sic]. Both Leopold and Wolfgang Mozart thought highly of his works, and Haydn's elder brother Joseph concurred in their good opinion. ${ }^{22}$

According to Charles Sherman, there were three main reasons why Michael Haydn has not been better remembered. Firstly, the name "Haydn" automatically became a referral to his brother Joseph. Secondly, his best music was composed for the church, and thus not as widely known. And lastly, at the time of Sherman's research, almost nothing written by Michael could be found in print. It seemed that Michael was not very diligent and permitted copying of his manuscripts.

In his 1967 dissertation, Sherman stated that primary material still needed to be collected and research completed in order to provide the resources on what the works of Michael Haydn represent to music history. Sherman himself started to collect materials along with fellow scholars to further the research of Michael Haydn's life and composition. In this bibliography, the reader will find more recent resources including research documents specifically related to his masses. Considering that Michael Haydn was such a prolific mass composer, there are still possibilities of new findings for the scholar who would like to further investigate this subject, thus increasing the availability of materials in English.

... his mastery of the genre [church music] assures him a place of honor among the composers of his time. In his works, Haydn achieved a synthesis of baroque polyphony and classical symphonic procedure that defined for later eighteenth century the archetypical style for sacred music. In this light, Michael

\footnotetext{
22 Sherman, Charles Henry. "The Masses of Johann Michael Haydn: A Critical Survey of Sources." (Ph.D. diss., University of Michigan, Ann Arbor, 1967), 2/3. ProQuest Dissertations and Theses Global. The two paragraphs that follow are also based on this document.
} 
Haydn's church works, and particularly his Masses, deserved to stand with the symphonies of Joseph Haydn and with the opera and piano concertos of Wolfgang Amadeus Mozart as the finest musical creations of the age. ${ }^{23}$

Michael Haydn composed over 30 masses, but most of his works did not find their way to the publishers. After the research of Sherman, the German publisher Carus-Verlag published any urtext editions of Michael's masses on which Charles Sherman had collaborated as one of the editors. The works edited by Carus are the ones included in this catalog. A number of bibliographies about Michael Haydn and his works are explored in German, but as previously stated, the purpose of the current document is to provide material in the English language thus, the bibliography is not as extensive as one will see in Beethoven's, F. J. Haydn's or Mozart's bibliographies.

Although many of their predecessors were highly esteemed during their lifetime, the first notable Mass composer in this era was Johann Michael Haydn (1737-1806), the younger brother of Franz Joseph Haydn and the Salzburg colleague of Mozart. ${ }^{24}$

23 Sherman, Charles Henry. "The Masses of Johann Michael Haydn: A Critical Survey of Sources." (Ph.D. diss., University of Michigan, Ann Arbor, 1967), 12. ProQuest Dissertations and Theses Global.

${ }^{24}$ Alwes, Chester L. A History of Western Choral Music. (New York: Oxford University Press, 2015$) 334$. 


\section{Bibliography}

\section{Journal Articles:}

Arenas, Erick. "Evaluating the Eighteenth-Century Legacy of the Fuxian Liturgical Style: The Solemn Idiom and Michael Haydn.” In Sakralmusik Im Habsburgerreich 1570-1770, by Herausgegeben and Erhardt Tassilo, 69-76. Wien: Austrian Academy of Sciences Press, 2013. Accessed June 14, 2020. www.jstor.org/stable/j.ctt1vw0pn0.8.

Holmes, E. "Haydn's Masses." The Musical Times and Singing Class Circular 7, no. 150 (1855): 83-85. Accessed June 14, 2020. doi:10.2307/3370008.

MacIntyre, Bruce. “Michael Haydn's Early Masses and Their Viennese Context.” In Haydn: The Online Journal of the Haydn Society in North America 9, no.2 (2019). Accessed July 5, 2020. https://www.rit.edu/affiliate/haydn/michael-haydns-early-masses-and-their$\underline{\text { viennese-context }}$

Miller, Dale. "The Choral Graduals of Johann Michael Haydn: Elegant Additions to the Performance Repertoire.” The Choral Journal 39, no. 9 (1999): 9-18. Accessed June 14, 2020. www.jstor.org/stable/23552783.

Pauly, Reinhard G. "Some Recently Discovered Michael Haydn Manuscripts." Journal of the American Musicological Society 10, no. 2 (1957): 97-103. Accessed June 14, 2020. doi:10.2307/830262.

\section{Theses and Dissertations:}

Arenas, Erick. "Johann Michael Haydn and the Orchestral Solemn Mass in Eighteenth-Century Vienna and Salzburg.” Ph.D. diss., Stanford University, Stanford, 2013. ProQuest Dissertations and Theses Global. 
Blazin, Dwight C. "Michael Haydn and "the Haydn Tradition": A Study of Attribution, Chronology, and Source Transmission.” Ph.D. diss., New York University, New York, 2004. ProQuest Dissertations \& Theses Global.

Clousing, Harold Wesley. "The Reforms of Joseph II of Austria on Church Music and Their Influence on the Works of Michael Haydn.” M.A. thesis, California State University, Long Beach, 1975. ProQuest Dissertations and Theses Global.

Pauly, Reinhard G. "Michael Haynd's Latin Proprium Missae Compositions.” PhD diss., New Haven, Yale University, 1956. ProQuest Dissertations \& Theses Global.

Poland, Jeffrey Thomas. "Michael Haydn’s Masses and Requiem Mass Compositions (Mozart, Salzburg, Austria).” D.M.A. diss., University of Cincinnati, Cincinnati, 1984. ProQuest Dissertations and Theses Global.

Sherman, Charles Henry. "The Masses of Johann Michael Haydn: A Critical Survey of Sources." Ph.D. diss., University of Michigan, Ann Arbor, 1967. ProQuest Dissertations and Theses Global. 
Vienna, 1758

Scoring: SATB choir, 2 trumpets in C, 2 violins, organ, continuo.

Editions available on IMSLP: none.

Publishers: Carus.

MH 13 Missa Sancti Cyrilli et Methodii

Vienna $[?]^{25}, 1758$

Scoring: SATB soloists, SATB choir, 2 trumpets in C (2 high - clarini, 2 low - trombe), 3

trombones, timpani, 2 violins, continuo.

Editions available on IMSLP: none.

Publishers: Carus.

\section{MH 15 Missa Beatissimae Virginis Mariae}

Grosswardein, 1758-1760 [62? $]^{26}$

Scoring: SATB soloists, SATB choir, 2 trumpets, 2 trombones, timpani, 2 violins, continuo.

Editions available on IMSLP: none.

Publishers: Carus.

${ }^{25}$ Question marks means the information is not conclusive.

${ }^{26}$ Date is not conclusive. 
Grosswardein [?] $]^{27}, 1758-60$

Scoring: SATB soloists, SATB choir, 2 trumpets, 3 trombones, timpani, 2 violins, organ, continuo.

Editions available on IMSLP: none.

Publishers: Carus.

Theses and Dissertation:

Killian, George Walter, Jr. "Johann Michael Haydn's "Missa Sancti Josephi”: Edition and Analysis.” D.M.A. diss., Arizona State University, Tempe, 2000. ProQuest Dissertations and Theses Global.

\section{MH 17 Missa Sancti Gabrielis}

Salzburg, 1760/68

Scoring: SATB soloists, SATB choirs, 2 trumpets in C, timpani, 2 violins, continuo.

Editions available on IMSLP: Fritz Brodersen (n.d.)

Publishers: Carus.

${ }^{27}$ Location of composition is not conclusive. 


\section{MH 56 Missa Sanctae Crucis}

Grosswardein, 1765

Scoring: SATB choir a cappella.

Editions available on IMSLP: none.

Publishers: Carus.

MH 87 Missa Sancti Raphaelis

Salzburg, 1865-68

Scoring: SATB choir, 2 oboes, 4 trumpets in C (2 clarini, 2 trombe), timpani, 2 violins, organ, continuo.

Editions available on IMSLP: none.

Publishers: Carus.

MH 109 Missa Sancti Nicolai Tolentini

Salzburg, 1768

Scoring: SS soloists, treble choir, 2 trumpets in C, timpani, continuo.

Editions available on IMSLP: none.

Publishers: Carus. 
Salzburg, 1772

Scoring: SATB choir, 2 oboes, 4 trumpets in C (2 clarini, 2 trombe), 3 trombones, timpani, 2 violins, continuo.

Editions available on IMSLP: none.

Publishers: Carus.

MH 229 Missa Sancti Amandi (Lambacher Messe/ Missa Lambacensis)

Salzburg, 1776

Scoring: SATB choir, 2 oboes, 4 trumpets, timpani, 2 violins, continuo.

Editions available on IMSLP: none.

Publishers: Carus.

Theses and Dissertations:

Sowers, Richard Louis. "Johann Michael Haydn's "Missa Sancti Amandi": Edition and Commentary." DMA diss., Arizona State University, Tempe, 1991. ProQuest Dissertations and Theses Global. 
Salzburg, 1777

Scoring: SATB soloists, SATB choir, 2 oboes soloists, 2 orchestra oboes, 2 bassoons, 3

trombones, organ, continuo.

Editions available on IMSLP: none.

Publishers: Carus.

\section{MH 257 Missa Sancti Aloysii}

Salzburg, 1777

Scoring: SSA soloists, SSA choirs, 2 violins, organ, continuo.

Editions available on IMSLP: none.

Publishers: Carus. 
Salzburg, 1786

Scoring: SATB soloist, SATB choir, 2 oboes, 2 trumpets in C, timpani, 2 violins, continuo.

Editions available on IMSLP: none.

Publishers: Carus.

Theses and Dissertations:

Donaldson, Donald Don. "The Messa Della Benedicenza": A Mass by Michael Haydn, 17371806." D.M.A. diss., University of Missouri - Kansas City, 1975. ProQuest Dissertations and Theses Global.

MH 530 Missa in Honorem Sancti Gotthardi (Admont Mass)

Salzburg, 1792

Scoring: SATB soloists, SATB choir, 2 oboes, 2 trumpets, timpani, 2 violins, organ.

Editions available on IMSLP: none.

Publishers: Carus.

MH 546 Missa in Honorem Sanctae Ursulae (Chiemsee Messe)

Salzburg, 1793

Scoring: SATB soloists, SATB choir, 2 trumpets, timpani, 2 violins, continuo.

Editions available on IMSLP: none.

Publishers: Carus. 
MH 551 Missa pro Quadragesima

Salzburg, 1794

Scoring: SATB choir, continuo.

Editions available on IMSLP: none.

Publishers: Carus.

\section{MH 552 Missa Quadragesimalis}

Salzburg, 1794

Scoring: SATB choir, continuo. (Reuse of the Missa Dolorum Beatissimae Virginis Mariae)

Editions available on IMSLP: none.

Publishers: Carus.

\section{MH 553 Missa tempore Quadragesimae}

Salzburg, 1794

Scoring: SATB choir, continuo.

Editions available on IMSLP: Österreichischer Bundesverlag (1915).

Publishers: Carus. 
Salzburg, 1801

Scoring: SATB soloists, SATB choir, 2 oboes, 2 trumpets in C, timpani, 2 violins, viola, organ, continuo.

Editions available on IMSLP: none.

Publishers: Carus.

\section{MH 826 Missa sub titulo Sancti Francisci Seraphici}

Salzburg, 1803

Scoring: SATB soloists, SATB choir, 2 oboes, 2 trumpets, timpani, strings, continuo.

Editions available on IMSLP: none.

Publishers: Carus. 


\section{MH 837 Missa sub titulo Sancti Leopoldi}

Salzburg, 1805

Scoring: SSA soloists, treble choir, 2 violins, continuo

Editions available on IMSLP: none.

Publishers: Carus.

Journal Articles:

Jackson, Chris. “St. Leopold Mass.” Choral Journal 48, n. 8 (2008): 107-8.

http://search.ebscohost.com.www.libproxy.wvu.edu/login.aspx?direct=true $\& d b=m a h \& A$ $\underline{\mathrm{N}=31269040 .}$. 


\section{Wolfgang Amadeus Mozart (1756-1791)}

Mozart's eighteen Masses represent two main types, half of them of the Missa brevis class. Since the Missa brevis is designed for use on a normal Sunday, the instrumental accompaniment is generally reduced to a minimum. Mozart usually set such Masses for an orchestra of two violins, with cello, bass, and organ on the continuo. (Conforming to the traditional practice at the Salzburg Cathedral, he did not include viola if the Mass was intended for that church). The vocal forces usually consist of soloists and a four-voice choir, with solo passages brief and emerging out of the choral texture, as was the custom of the time. If extended solo or ensemble settings appear, they are most likely to be in the quieter movements - the Benedictus and Agnus Dei. Even though the longer texts are set as single movements, Mozart generally divides the Agnus Dei into two separated sections, composing the final Dona nobis pacem as an independent separated movement. ${ }^{28}$

To construct this catalog, the main references were Zaslaw and Cowdery (1990), Alwes (2015), and Shrock (2017). Wikipedia was also used as a starting point to some references not presented in the books above mentioned. IMSLP was used to confirm the scoring of the pieces and to check the scores when the information differed in the resources above mentioned.

Based on the research for this document, it is clear that in the English language the most studied and recorded bibliographic materials are for Mozart's C minor Mass, K427, recognized as Mozart's Great Mass. According to Kiu Ho Mok (2008) most of Mozart's masses were composed for the Archbishop Hieronymus Colloredo and there were rules to be followed. By the time of the composition of K.427, Mozart was living in Vienna, and this composition was not dictated by his duties with a church but by his own desire, thus, many elements from opera and instrumental music were freely included by Mozart in his C Minor Mass, K427.

This bibliography starts with documents that provide studies of Mozart and his relationship with the church, the style of his compositions and suggestions for performance

\footnotetext{
${ }^{28}$ Ulrich, Homer. A Survey of Choral Music. (New York: Harcourt Brace Jovanovich, Inc.,
} 1973), 123. 
practices. There are also studies on Mozart's sacred choral music and its use in the liturgy. The reader will find at least one bibliography reference for every mass, therefore, there are still works that students and scholars can explore within the realm of Mozart's masses. 


\section{Bibliography}

\section{Books:}

Anderson, Emily, ed. and trans. The Letters of Mozart and His Family. 1st American Revised ed. New York: Norton, 1985.

Zaslaw, Neal, and William Cowdery. The Compleat Mozart: A Guide to the Musical Works of Wolfgang Amadeus Mozart. New York: W. W. Norton \& Company, 1990.

\section{Book Chapters:}

Alwes, Chester L. “The Mass (1750-1900).” In A History of Western Choral Music, 334-369. New York: Oxford University Press, 2015.

Corneilson, Paul. "Mozart as a Vocal Composer." In The Cambridge Companion to Mozart, edited by Simon P. Keefe, 118-130. Cambridge: Cambridge University Press, 2003.

Eisen, Cliff. “Mozart and Salzburg.” In The Cambridge Companion to Mozart, edited by Simon P. Keefe, 7-21. Cambridge: Cambridge University Press, 2003.

\section{Journal Articles:}

Beckmann-Collier, Aimee. "Sacred Choral Music in the Classical Era." The Choral Journal 31, no. 9 (1991): 5-8. Accessed June 14, 2020. www.jstor.org/stable/23548117.

Cassel, David C. "Some Performance Suggestions for The "Mozart Missae Breves and Others of His Works"." The Choral Journal 26, no. 1 (1985): 7-11. Accessed June 7, 2020. www.jstor.org/stable/23546876.

De Catanzaro, Christine D. “On the Performance of Mozart's Salzburg Masses.” The Choral Journal 34, no. 3 (1993): 9-15. Accessed June 7, 2020. www.jstor.org/stable/23549308. 
Dean, Scott. "Music in Worship: Mozart's Sacred Choral Music Part Two." The Choral Journal 47, no. 1 (2006): 37-42. Accessed June 7, 2020. www.jstor.org/stable/23554669.

Dean, Scott. "Music In Worship: Mozart's Sacred Choral Music, Part 1.” The Choral Journal 46, no. 12 (2006): 77-80. Accessed June 7, 2020. www.jstor.org/stable/23556464.

Eisen, Cliff. “Mozart's Salzburg Orchestras.” Early Music 20, no. 1 (1992): 89-103. Accessed June 12, 2020. www.jstor.org/stable/3127670.

Green, Edward. "The Principle of Chromatic Saturation in the Late Choral Music of Mozart and Haydn.” The Choral Journal 46, no. 12 (2006): 34-50. Accessed June 12, 2020. www.jstor.org/stable/23556460.

Lösel, Steffen. "May Such Great Effort Not Be in Vain": Mozart on Divine Love, Judgment, and Retribution.” The Journal of Religion 89, no. 3 (2009): 361-400. Accessed June 12, 2020. doi:10.1086/597984.

Rosenthal, Carl A. "Salzburg Influences in Mozart's Church Music." Bulletin of the American Musicological Society, no. 8 (1945): 3-4. Accessed June 7, 2020. doi:10.2307/829374.

Rosenthal, Karl August, and Theodore Baker. "The Salzburg Church Music of Mozart and His Predecessors.” The Musical Quarterly 18, no. 4 (1932): 559-77. Accessed June 7, 2020. www.jstor.org/stable/738939.

Rosenthal, Karl August, and Arthur Mendel. "Mozart's Sacramental Litanies and Their Forerunners.” The Musical Quarterly 27, no. 4 (1941): 433-55. Accessed June 12, 2020. www.jstor.org/stable/739493.

Weber, Paul Mathew. 2011. "Mozart's Ave Verum Corpus and Eighteenth-Century Musical Style." Sacred Music 138 (1): 41-54. 
http://search.ebscohost.com.www.libproxy.wvu.edu/login.aspx?direct=true\&db=mah\&A $\underline{\mathrm{N}=61900623}$.

Zaslaw, Neal. "Mozart, Haydn and the Sinfonia Da Chiesa." The Journal of Musicology 1, no. 1 (1982): 95-124. Accessed June 14, 2020. doi:10.2307/763639.

\section{Theses and Dissertations:}

Black, David Ian. "Mozart and the Practice of Sacred Music, 1781-1791.” PhD diss., Harvard University, Cambridge, 2007. ProQuest Dissertations and Theses Global.

Welch, Susan Corine. "The Complete Missae Solemnes of Wolfgang Amadeus Mozart: A Comparative Analysis (K.139, 66, 167, 262, 257, 317, AND 337).” D.M.A. diss., The University of Oklahoma, Norman, 1987. ProQuest Dissertations and Theses Global.

Windt, Nathan. “A Conductor's Guide to Selected Short, Pre-Viennese Liturgical and Sacred Choral Works of Wolfgang Amadeus Mozart.” D.M.A. diss., University of Cincinnati, Cincinnati, 2008. ProQuest Dissertations and Theses Global. 


\section{K. 49 Missa brevis in G major (K6 47d $)^{29}$}

Vienna, 1769 (October or November)

Scoring: SATB soloists, SATB choir, 3 trombones, organ, strings, continuo.

Editions available on IMSLP: Breitkopf \& Härtel (1877) and Bärenreiter-Verlag (1968).

Publishers: Breitkopf, Carus, E. F. Kalmus.

Journal Articles:

Holmes, E. “Mozart's Masses. Nos. VIII., IX." The Musical Times and Singing Class Circular 5, no. 107 (1853): 165-71. Accessed June 7, 2020. doi:10.2307/3370784.

\section{Theses and Dissertations:}

Cassel, David Cunningham. “A Conductor’s Analysis of the Missae Breves of Wolfgang Amadeus Mozart.” DMA diss., Indiana University, Bloomington, 1977. ProQuest Dissertation and Theses Global. (pages 22-64)

29 "If the composition has ever borne a different number in any intermediate edition of the Köchel Catalogue, that number is also given in parenthesis." Zaslaw \& Cowdery, 1990, xiii (terms and abbreviations). 


\section{K. 65 Missa brevis in D minor (K6 61a)}

Salzburg, 1769 (January 14)

Scoring: SATB soloists, SATB choir, 3 trombones $^{30}$, organ, strings, continuo.

Editions available on IMSLP: Breitkopf \& Härtel (1877) and Bärenreiter-Verlag (1968).

Publishers: Bärenreiter, Breitkopf, Carus, E. F. Kalmus.

\section{Theses and Dissertations:}

Cassel, David Cunningham. “A Conductor's Analysis of the Missae Breves of Wolfgang Amadeus Mozart.” DMA diss., Indiana University, Bloomington, 1977. ProQuest Dissertation and Theses Global. (pages 65-88)

\footnotetext{
30 Trombones are included in the Bärenreiter-Verlag (1968) score edition available on IMSLP, but are omitted in the Breitkopf \& Härtel (1877) edition available on IMSLP. Most likely it is omitted because trombone colla parte were common practice at the time, therefore, saving printing space, paper, and ink.
} 


\section{K. 66 Missa in C major, "Dominicus"}

Salzburg, 1769 (October)

Scoring: SATB soloists, SATB choir, 2 oboes, 2 horns, 4 trumpets, 3 trombones, timpani, organ, strings, continuo.

Editions available on IMSLP: Breitkopf \& Härtel (1877) and Bärenreiter-Verlag (1968).

Publishers: Bärenreiter, Breitkopf, Carus.

\section{These and Dissertations:}

Welch, Susan Corine. "The Complete Missae Solemnes of Wolfgang Amadeus Mozart: A Comparative Analysis (K.139, 66, 167, 262, 257, 317, AND 337).” D.M.A. diss., The University of Oklahoma, Norman, 1987. ProQuest Dissertations and Theses Global. 


\section{K. 139 Missa solemnis in C minor, “Waisenhausmesse” (K3 114a, K6 47a)}

Vienna, 1768 (autumn)

Scoring: SATB soloists, SATB choir, 2 oboes, 2 trumpets, ${ }^{31} 3$ trombones, timpani, organ, strings, continuo.

Editions available on IMSLP: Breitkopf \& Härtel (1877) and Bärenreiter-Verlag (1968).

Publishers: Bärenreiter, Breitkopf, Carus.

\section{Theses and Dissertations:}

Welch, Susan Corine. "The Complete Missae Solemnes of Wolfgang Amadeus Mozart: A Comparative Analysis (K.139, 66, 167, 262, 257, 317, AND 337).” D.M.A. diss., The University of Oklahoma, Norman, 1987. ProQuest Dissertations and Theses Global.

${ }^{31}$ Zaslaw and Cowdery mention 4 trumpets. Chester Alwes mentions 2 trumpets. In the scores available on IMSLP, Bärenreiter-Verlag include 2 trumpets. Breitkopf \& Härtel does not include trumpets. 


\section{K. 140 Missa brevis in G major (K6 Anh C1.12)}

Salzburg, 1773. (authorship questionable)

Scoring: SATB soloist, SATB choir, 2 violins, continuo, organ.

Editions available on IMSP: Bärenreiter-Verlag (1968).

Publishers: Bärenreiter, Breitkopf, Carus.

\section{Theses and Dissertations:}

Cassel, David Cunningham. “A Conductor's Analysis of the Missae Breves of Wolfgang Amadeus Mozart.” DMA diss., Indiana University, Bloomington, 1977. ProQuest Dissertation and Theses Global. (Pages 89-120) 


\section{K. 167 Missa in C major, “Trinitatis”}

Salzburg, 1773 (June. The Kyrie was written in an earlier date)

Scoring: SATB soloists, SATB choir, 2 oboes, 4 trumpets, 3 trombones, timpani, organ, 2 violins, continuo.

Editions available on IMSLP: Breitkopf \& Härtel (1877) and Bärenreiter-Verlag (1975).

Publishers: Bärenreiter, Breitkopf, Carus.

\section{Theses and Dissertations:}

Welch, Susan Corine. "The Complete Missae Solemnes of Wolfgang Amadeus Mozart: A Comparative Analysis (K.139, 66, 167, 262, 257, 317, AND 337).” D.M.A. diss., The University of Oklahoma, Norman, 1987. ProQuest Dissertations and Theses Global. 


\section{K. 192 Missa brevis in F major ${ }^{32}$ (K6 186f)}

Salzburg, 1774 (June 24)

Scoring: SATB soloists, SATB choir, 2 trumpets $^{33}, 3$ trombones, organ, 2 violins, continuo.

Editions available on IMSLP: Holograph Manuscript (1774), Paris: P. Porro (n.d.), Breitkopf \& Härtel (1877), Augsburg: Anton Böhm (n.d.) and Bärenreiter-Verlag (1975).

Publishers: Bärenreiter, Breitkopf, Carus.

\section{Journal Articles:}

Holmes, E. "Mozart's Masses. Nos. III. IV.” The Musical Times and Singing Class Circular 5, no. 103 (1852): 101-08. Accessed June 7, 2020. doi:10.2307/3369966.

Long, Janice. "Missa Brevis In F Major, K. 192: Wolfgang Amadeus Mozart.” The Choral Journal 18, no. 6 (1978): 5-7. Accessed June 7, 2020. www.jstor.org/stable/23545019.

\section{Theses and Dissertations:}

Cassel, David Cunningham. “A Conductor's Analysis of the Missae Breves of Wolfgang Amadeus Mozart.” DMA diss., Indiana University, Bloomington, 1977. ProQuest Dissertation and Theses Global. (Pages 121-158)

\footnotetext{
32 "Little Credo" according to Zaslaw and Cowdery.
}

${ }^{33}$ The trumpets were added later by Mozart. 


\section{K. 194 Missa brevis in D major (K6 186h)}

Salzburg, 1774 (August 8)

Scoring: SATB soloists, SATB choir, 3 trombones, organ, 2 violins, continuo.

Editions available on IMSLP: Breitkopf \& Härtel (1877) and Bärenreiter-Verlag (1975).

Publishers: Bärenreiter, Breitkopf, Carus.

Journal Articles:

Holmes, E. “Mozart’s Masses. Nos. V., VI., VII.” The Musical Times and Singing Class Circular 5, no. 104 (1853): 117-18. Accessed June 7, 2020. doi:10.2307/3370537.

Jost, John. “Choral-Orchestral Articulation and Phrasing in Mozart's “Missa Brevis in D,” K. 194.” The Choral Journal 42, no. 4 (2001): 9-15. Accessed June 7, 2020. www.jstor.org/stable/23553974.

\section{Theses and Dissertations:}

Cassel, David Cunningham. “A Conductor's Analysis of the Missae Breves of Wolfgang Amadeus Mozart.” DMA diss., Indiana University, Blomington, 1977. ProQuest Dissertation and Theses Global. (Pages 159-187)

Southorn, Elisabeth B. "Mozart's "Missa Brevis”, in D Major, K. 194: Meaning Revealed through Historical, Biographical and Analytic Perspectives.” M.A. thesis, San Jose State University, San Jose, 1994. ProQuest Dissertations and Theses Global. 


\section{K. 220 Missa Brevis in C major, "Spatzenmesse" (K6 196b)}

Salzburg, $1775-1777$

Scoring: SATB soloists, SATB choir, 2 trumpets, 3 trombones, timpani, organ, 2 violins, continuo.

Editions available on IMSLP: Breitkopf \& Härtel (1877) and Bärenreiter-Verlag (1975).

Publishers: Bärenreiter, Breitkopf, Carus.

\section{Journal Articles:}

Holmes, E. “Mozart's Masses. Nos. V., VI., VII.” The Musical Times and Singing Class Circular 5, no. 104 (1853): 117-18. Accessed June 7, 2020. doi:10.2307/3370537.

Rice, John A. “Adding Birds to Mozart's “Sparrow Mass”: An Arrangement with Children’s Instruments by Paul Wranitzky." The Choral Journal 46, no. 12 (2006): 22-32. Accessed June 7, 2020. www.jstor.org/stable/23556459.

\section{Theses and Dissertations:}

Cassel, David Cunningham. “A Conductor's Analysis of the Missae Breves of Wolfgang Amadeus Mozart.” DMA diss., Indiana University, Bloomington, 1977. ProQuest Dissertation and Theses Global. (Pages 223-250) 


\section{K. 257 Missa in C major, “Credo"}

Salzburg, 1776 (November)

Scoring: SATB soloists, SATB choir, 2 oboes, 2 trumpets, 3 trombones, timpani, organ, 2 violins, continuo.

Editions available on IMSLP: Holograph Manuscript (1776), Breitkopf \& Härtel (1878) and Bärenreiter-Verlag (1980).

Publishers: Bärenreiter, Breitkopf, Carus.

Journal Articles:

Holmes, E. "Mozart's Masses. No. II.” The Musical Times and Singing Class Circular 5, no. 102 (1852): 83-85. Accessed June 7, 2020. doi:10.2307/3370777.

\section{Theses and Dissertations:}

Welch, Susan Corine. "The Complete Missae Solemnes of Wolfgang Amadeus Mozart: A Comparative Analysis (K.139, 66, 167, 262, 257, 317, and 337).” D.M.A. diss., The University of Oklahoma, Norman, 1987. ProQuest Dissertations and Theses Global. 


\section{K. 258 Missa brevis in C major, "Spauermesse"}

Salzburg, 1775-1776[?] $]^{34}$ (December)

Scoring: SATB soloists, SATB choir, 2 oboes $^{35}, 2$ trumpets, 3 trombones, timpani, organ, 2 violins, continuo.

Editions available on IMSLP: Holograph Manuscript (1776), Breitkopf \& Härtel (1878) and Bärenreiter-Verlag (1980).

Publishers: Bärenreiter, Breitkopf, Carus.

\section{Journal Articles:}

Holmes, E. "Mozart's Masses. Nos. III. IV." The Musical Times and Singing Class Circular 5, no. 103 (1852): 101-08. Accessed June 7, 2020. doi:10.2307/3369966.

\section{Theses and Dissertations:}

Cassel, David Cunningham. “A Conductor's Analysis of the Missae Breves of Wolfgang Amadeus Mozart.” DMA diss., Indiana University, Bloomington, 1977. ProQuest Dissertation and Theses Global. (Pages 251-282)

${ }^{34}$ Date of composition in not conclusive.

35 Oboes were added later by Mozart. 


\section{K. 259 Missa brevis in C, “Organ Solo Mass”}

Salzburg, 1775-1776[?] $]^{36}$ (December)

Scoring: SATB soloists, SATB choir, 2 oboes, 2 trumpets, 3 trombones, timpani, organ, 2 violins, continuo.

Editions available on IMSLP: Holograph Manuscript (1776), Breitkopf \& Härtel (1878) and Bärenreiter-Verlag (1980).

Publishers: Bärenreiter, Breitkopf, Carus.

Journal Articles:

Holmes, E. “Mozart's Masses. Nos. X., XI.” The Musical Times and Singing Class Circular 5, no. 108 (1853): 179-81. Accessed June 7, 2020. doi:10.2307/3370341.

\section{Theses and Dissertations:}

Cassel, David Cunningham. “A Conductor's Analysis of the Missae Breves of Wolfgang Amadeus Mozart.” DMA diss., Indiana University, Bloomington, 1977. ProQuest Dissertation and Theses Global. (Pages 283-313)

\footnotetext{
${ }^{36}$ Date of composition is not conclusive.
} 


\section{K. 262 Missa longa in C major (K6 246a)}

Salzburg, 1775 (May, June, or July)

Scoring: SATB soloists, SATB choir, 2 oboes, 2 horns, 2 trumpets, 3 trombones, timpani ${ }^{37}$, organ, 2 violins, continuo.

Editions available on IMSLP: Breitkopf \& Härtel (1878) and Bärenreiter-Verlag (1975).

Publishers: Bärenreiter, Breitkopf, Carus.

\section{Journal Articles:}

Holmes, E. "Mozart's Masses. No. I." The Musical Times and Singing Class Circular 5, no. 101 (1852): 67-70. Accessed June 7, 2020. doi:10.2307/3370180.

Welch, Susan C. "Mozart's Missa Solemnis K. 262 An Overlooked Masterpiece.” The Choral Journal 30, no. 2 (1989): 9-13. Accessed June 7, 2020. www.jstor.org/stable/23547756.

\section{Theses and Dissertations:}

Welch, Susan Corine. "The Complete Missae Solemnes of Wolfgang Amadeus Mozart: A Comparative Analysis (K.139, 66, 167, 262, 257, 317, AND 337).” D.M.A. diss., The University of Oklahoma, Norman, 1987. ProQuest Dissertations and Theses Global.

\footnotetext{
37 The timpani was added later by Mozart.
} 
Salzburg, 1777

Scoring: SATB soloists, SATB choir, 3 trombones, organ, 2 violins, continuo.

Editions available on IMSLP: Breitkopf \& Härtel (1878).

Publishers: Bärenreiter, Breitkopf, Carus.

Journal Articles:

Holmes, E. "Mozart's Masses. Nos. X., XI.” The Musical Times and Singing Class Circular 5, no. 108 (1853): 179-81. Accessed June 7, 2020. doi:10.2307/3370341.

\section{Theses and Dissertations:}

Cassel, David Cunningham. “A Conductor’s Analysis of the Missae Breves of Wolfgang Amadeus Mozart.” DMA diss., Indiana University, Bloomington, 1977. ProQuest Dissertation and Theses Global. (Pages 188-222) 


\section{K. 317 Missa in C major, “Coronation”}

Salzburg, 1779 (March)

Scoring: SATB soloists, SATB choir, 2 oboes, 2 horns, 2 trumpets, 3 trombones, timpani, organ, 2 violins, continuo.

Editions available on IMSLP: Holograph Manuscript (1779), Breitkopf \& Härtel (1878).

Publishers: Bärenreiter, Breitkopf, Carus.

Journal Articles:

Holmes, E. "Mozart's Masses. No. I.” The Musical Times and Singing Class Circular 5, no. 101 (1852): 67-70. Accessed June 7, 2020. doi:10.2307/3370180

\section{Theses and Dissertations:}

Welch, Susan Corine. "The Complete Missae Solemnes of Wolfgang Amadeus Mozart: A Comparative Analysis (K.139, 66, 167, 262, 257, 317, and 337).” D.M.A. diss., The University of Oklahoma, Norman, 1987. ProQuest Dissertations and Theses Global.

Wiens, Paul Willard. “A Conductor's Preparatory Analysis of "Missa in C Major” (Coronation Mass) K. 317, by Wolfgang Amadeus Mozart." D.M.A diss., The University of Iowa, Iowa City, 1979. 


\section{K. 337 Missa solemnis in C major}

Salzburg, 1780 (March)

Scoring: SATB soloists, SATB choir, 2 oboes, 2 bassoons, 2 horns, 2 trumpets, 3 trombones, timpani, organ, 2 violins, continuo.

Editions available on IMSLP: Holograph Manuscript (1780), Breitkopf \& Härtel (1878).

Publishers: Bärenreiter, Breitkopf, Carus.

Journal Articles:

Holmes, E. "Mozart's Masses. No. 14.” The Musical Times and Singing Class Circular 6, no. 143 (1855): 367-70. Accessed June 7, 2020. doi:10.2307/3370081.

\section{Theses and Dissertations:}

Humphrey, Mark Aaron. “The Stylistic and Historical Significance of Mozart's Mass in C Major K. 337.” D.M.A., University of Southern California, Los Angeles, 2006. ProQuest Dissertations and Theses Global.

Welch, Susan Corine. "The Complete Missae Solemnes of Wolfgang Amadeus Mozart: A Comparative Analysis (K.139, 66, 167, 262, 257, 317, AND 337).’D.M.A. diss., The University of Oklahoma, Norman, 1987. ProQuest Dissertations and Theses Global. 


\section{K. 427 Missa in C minor (K6 417a)}

Vienna, from 1782 (July) to 1783 (May)

Scoring: SSTB soloists, SATB choir (divisi), 2 oboes $^{38}, 2$ bassoons, 2 horns, 2 trumpets, 3 trombones, timpani, organ, strings, continuo.

Editions available on IMSLP: Manuscript, Breitkopf \& Härtel (1882), Bärenreiter-Verlag (1983), Philip Legge (2001-09).

Publishers: Bärenreiter, Breitkopf, Carus, Oxford.

\section{Book Chapters:}

Landon, H. C. Robbins "Mozart's Mass in C minor, K. 427.” In Studies in Musical Sources and Style: Essays in Honor of Jan LaRue, edited by Eugene K. Wolf and Edward H. Roesner, 419-423. Madison, WI: A-R Editions, 1990.

Leisinger, Ulrich. 'Haydn's Copy of the B-minor Mass and Mozart's Mass in C minor: Viennese Traditions of the B-minor Mass.” In Exploring Bach's B-minor Mass, edited by Robin Leaver, Jan Smaczny, and Yo Tomita, 217-243. Cambridge: Cambridge University Press, 2013.

\section{E-books:}

Greene, David B. The Spirituality of Mozart's Mass in C Minor, Bach's Mass in B Minor, and Messiaen's Quartet for the End of Time: When Hearing Sacred Music Is Relating to God. Lewiston: Edwin Mellen Press, 2011. http://search.ebscohost.com.www.libproxy.wvu.edu/login.aspx?direct=true $\& d b=n l e b k \&$ $\underline{\mathrm{AN}=464187 .}$.

${ }^{38}$ One oboe is doubling the flute. 


\section{Journal Articles:}

Crabb, R. Paul. “Mozart's “Grand Mass in C Minor” K.427/417a.” The Choral Journal 26, no. 1 (1985): 13-22. Accessed June 7, 2020. www.jstor.org/stable/23546877.

Schenbeck, Lawrence. "Three New Editions of Mozart's "Great" "C Minor Mass"." The Choral Journal 32, no. 8 (1992): 21-28. Accessed June 7, 2020. www.jstor.org/stable/23548084. Newton, Timothy. "Mozart's Evolving “Great” Mass in C Minor, K. 427/417a.” The Choral Journal 46, no. 12 (2006): 52-73. Accessed June 7, 2020. www.jstor.org/stable/23556461.

\section{Theses and Dissertations:}

Crabb, Richard Paul. "Wolfgang Amadeus Mozart's "Grand Mass in C Minor K. 427/417A": A History and Comparative Analyses of Performance Editions.” Ph.D. diss., The Florida State University, Tallahassee, 1984. ProQuest Dissertations and Theses Global.

Mok, Kiu Ho. "Mozart's Salzburg Masses and the Mass in C minor, K. 427.” M.Ph. diss., The Chinese University of Hong Kong, Hong Kong, 2008.

Rice, Susan L. “Mozart's Late Liturgical Compositional Method: The Mass in C Minor, K. 427 and the Mass Movement Fragments, 1779-1791.” A. Mus. D. diss., University of Illinois at Urbana-Champaign, Urbana-Champaign, 2011. ProQuest Dissertations and Theses Global.

Smith, Elliott H. “Mozart's “Great” Mass: Sources, History, and Performance Practice.” D.M.A. diss., University of Notre Dame, Notre Dame, 2019. ProQuest Dissertations and Theses Global. 
Sousa, Gerald Anthony. "Wolfgang Amadeus Mozart Missa in C no. 11, k427 (417a): An Analysis for Performance.” D.Mus. diss., Indiana University, Bloomington, 1986. ProQuest Dissertations and Theses Global. 


\section{Ludwig Van Beethoven (1770-1827)}

Compared to his most famous peers Mozart and J. Haydn, Beethoven composed a smaller number of Catholic ordinary masses: only two. They were, however, large works and have received great attention from scholars and performers due to peculiar reasons:

Beethoven, who in Vienna never held court or church position, wrote only a few sacred works. His personal faith incorporated a significant dose of pantheism, though it embraced the biblical view of an eternal, omnipotent God. It is not certain whether he viewed Christ as divine, but themes of purity and suffering inspired his first substantial sacred piece, the oratorio Christ on the Mount of Olives (1803)[...]

Beethoven wrote two masses, both for the high nobility. The first was the mass in C (1807), commissioned by Prince Esterházy. Unfortunately the prince did not appreciate it, to the relief and delight of Konzertmeister Hummel. The second, the great Missa Solemnis in D (1823), was intended for the grand installation of Beethoven's friend and patron Archduke Rudolph as Archbishop of Olmütz. Beethoven began the work in 1819, but missed the 1820 deadline by three years.

The missa Solemnis is far more than sacred music designed for a liturgical context. It became a deeply personal statement, and one that Beethoven prepared for by a committed study of the Roman (Latin) Mass and Renaissance choral style... Writing this Mass, Beethoven broke away from rigid Classical structures, particularly in the melodic line, presenting a subjective vision that extended deep into the heart of Romanticism. ${ }^{39}$

There are a variety of opinions about Beethoven and the orthodoxy of his religious beliefs. The first part of this catalog includes documents that discuss Beethoven and his relationships with choral music, with Catholicism, and how his masses fit alongside his other compositions.

${ }^{39}$ Paxman, Jon. Classical Music:1600 - 2000: A Chronology. (China, Omnibus Press, 2014), 333. 


\section{Bibliography}

\section{Books:}

Abraham, Gerald. The New Oxford History of Music. Vol. 8: The Age of Beethoven 1790-1830. Oxford: Oxford University Press, 1982.

Clive, Peter. Beethoven and His World: A Biographical Dictionary. Oxford: Oxford University Press, 2001.

Mellers, Wilfrid. Beethoven and the Voice of God. London: Oxford University Press, 1983.

Paxman, Jon. Classical Music:1600 - 2000: A Chronology. China, Omnibus Press, 2014.

Solomon, Maynard. Beethoven. 2nd ed. New York: Schirmer Books, 1998.

\section{Book Chapters:}

Lockwood, Lewis. "Vocal Music". In Beethoven: The Music and the Life, 269-273. New York: W.W. Norton, 2003.

Solomon, Maynard. “The Quest for Faith.” In Beethoven Essays, 216-232. United Kingdom: Harvard University Press, 1990.

\section{Journal Articles:}

Forbes, Elliot. "Beethoven as a Choral Composer.” Proceedings of the Royal Musical Association 97 (1970): 69-82. Accessed June 7, 2020. www.jstor.org/stable/766192.

Robertson, Alec. "Beethoven and the Liturgy." The Musical Times 111, no. 1534 (1970): 1260262. Accessed June 7, 2020. doi:10.2307/955886. 


\section{Theses and Dissertations:}

Chong, Nicholas J. “Beethoven's Catholicism: A Reconsideration.” Ph.D. diss., Columbia University, New York, 2016. ProQuest Dissertations and Theses Global.

Strayer, Gene Paul. “The Theology of Beethoven's Masses.” Ph.D. diss., University of Pennsylvania, Philadelphia, 1991. ProQuest Dissertations and Theses Global.

Witcombe, Charles C. “Beethoven's Private God: An Analysis of the Composer's Markings in Sturm's “Betrachtungen”.” M.A. diss., San Jose State University, San Jose, 1998. Ann Arbor: ProQuest. Web. 21 June 2020.

\section{Periodicals:}

Ivry, Benjamin. “Just How Catholic Was Beethoven?” America 222, no. 13 (2020): 34-38. http://search.ebscohost.com.www.libproxy.wvu.edu/login.aspx?direct=true $\& d b=a 9 h \& A$ $\underline{N}=143469897$. 


\section{Missa in C Major, opus 86}

Eisenstadt, 1807

Scoring: SATB soloist, SATB choir, 2 flutes, 2 oboes, 2 clarinets in C, 2 bassoons, 2 horns, 2 trumpets, timpani, strings, organ.

Editions Available on IMSLP: Breitkopf \& Härtel (1807) (first edition) and (1864)

Publishers: Bärenreiter, Carus, Peters, Breitkopf \& Härtel, G. Henle Verlag (Urtext Edition study score), Eulenburg, Kalmus.

\section{Books:}

Abraham, Gerald. The New Oxford History of Music. Vol. 8 : The Age of Beethoven 1790-1830. Great Britain: Oxford University Press, 1982.

\section{Journal Articles:}

Fillion, Michelle “Beethoven's Mass in C and the Search for Inner Peace.” Beethoven Forum (University of Nebraska Press) 7, no.1 (1999): 1. http://search.ebscohost.com.www.libproxy.wvu.edu/login.aspx?direct=true $\& d b=a 9 h \& A$ $\underline{\mathrm{N}=6446594 .}$.

Holmes, E. “Beethoven's Mass in C.” The Musical Times and Singing Class Circular 8, no. 181 (1858): 199-202. Accessed June 7, 2020. doi:10.2307/3370408.

Holmes, E. "Beethoven's Mass in C (Concluded)." The Musical Times and Singing Class Circular 8, no. 182 (1858): 215-19. Accessed June 7, 2020. doi:10.2307/3371039. McGrann, Jeremiah W. "Haydn, A Prince, and Beethoven's Mass in C." The Choral Journal 50, no. 2 (2009): 8-23. Accessed June 7, 2020. www.jstor.org/stable/23560192. 
Stoltzfus, Fred. "Beethoven's "Mass in C" Notes on History, Structure, and Performance Practice.” The Choral Journal 23, no. 3 (1982): 26-30. Accessed June 7, 2020. www.jstor.org/stable/23545801.

Tours, Berthold. "Beethoven's Mass, in C and Haynd's Mass in Bflat (No.1)". The Musical Times and Singing Class Circular 19, no. 428 (1878): 553-54. Accessed June 7, 2020. doi:10.2307/3356309.

\section{Theses and Dissertations:}

Doiron, Ronald Edward. “Ludwig Van Beethoven's Mass in C, Op. 86: History, Musical Style, Analysis and Performance Considerations.” D.M.A. diss., University of Southern California, Los Angeles, 1992.

Frazes Hill, Cheryl. “A Conductor's Study of Beethoven’s Mass in C.” Ph.D. diss., Northwestern University, Evanston 1992.

Groher, George Malcolm. "A Study and Performance of the Mass in C Major by Ludwig Van Beethoven.” M.Mus. thesis, University of Southern California, Los Angeles, 1960.

McGrann, Jeremiah Walker R. "Beethoven's Mass in C, Opus 86: Genesis and Compositional Background. (Volumes I and II)." Ph.D. diss., Harvard University, Cambridge, 1991.

Park, Kyung Hee. "The Roles of Pamina and Papgena in "Die Zauberfloete" by Mozart, Adina in "L'Elesir d'Amore" by Donizetti and the Soprano Solo Parts in Beethoven's Mass in CMajor and the Choral Fantasia: A Performance Project.” D.M.A. diss., University of Maryland, College Park, 2001. Proquest Dissertations and Theses Global.

Stoltzfus, Fred Alan. "A Conductor's Analysis of "Mass in C, Op. 86" by Ludwig Van Beethoven.” D.M.A. diss., The University of Iowa, Iowa City, 1980. 


\section{Missa Solemnis, opus 123}

Saint Petersburg (1st performance), 1824 (April 7)

Scoring: SATB soloists, SATB choirs, strings, 2 flutes, 2 oboes, 2 clarinets in A, 2 bassoons, 4 horns in D, 2 trumpets in D, timpani in D and A, organ.

Editions Available at IMSLP: Ernst Eulenburg (1938), Breitkopf \& Härtel (1864), Schott (1827) (first edition).

Publishers: E.F.Kalmus, Dover Music Scores, Bärenreiter, Carus, Peters, Breitkopf \& Härtel, G. Henle Verlag (Urtext Edition - study score).

\section{Books:}

Anderson, Emily. The Letters of Beethoven, Vol. 1-3. London: MacMillan \& Co. Ltd., 1961.

Drabkin, William. Beethoven: Missa Solemnis. Cambridge, Cambridge University Press: 1991.

Abraham, Gerald. The New Oxford History of Music. Vol. 8: The Age of Beethoven 1790-1830. Oxford: Oxford University Press, 1982.

\section{Book Chapter:}

Cooper, Martin. “The Missa Solemnis. Op. 123.” In Beethoven: The Last Decade, 221-275. London: Oxford University Press, 1970

Ellison, Paul M. "Vocal and Choral Music with Orchestra: Five Case Studies." In The Key to Beethoven: Connecting Tonality and Meaning in His Music, 297-360. Hillsdale: Pendragon Press, 2014.

Lang, Paul Henry. "New Roads to Old Ideas in Beethoven's Missa Solemnis.” In The Creative World of Beethoven 163-?. New York: Norton, 1971. 
Summer, Robert J. "Ludwig van Beethoven: Missa Solemnis, Op. 23.” In Choral Masterworks from Bach to Britten: Reflections of a Conductor, 51-63. 1941. Reprint, Maryland: Scarecrow Press, 2007.

\section{Conference Presentation:}

Heinemann, Michael. 2013. "Suspended Time: The Fugue on Et Vitam Venturi Saeculi in the Credo of the Missa Solemnis." Journal of Musicological Research 32 (2-3): 225-32. http://search.ebscohost.com.www.libproxy.wvu.edu/login.aspx?direct=true \&db=rih\&AN $=\mathrm{A} 818820$.

\section{Journal Articles:}

Armitage-Smith, J. N. A. “Beethoven's Mass in D.” The Musical Times 98, no. 1376 (1957): 560. Accessed June 7, 2020. doi:10.2307/937079.

Carr-Richardson, Amy. “Handel's Messiah as Model and Source for Beethoven's Missa Solemnis." Musicological Explorations 13 (2012): 93-126. http://search.ebscohost.com.www.libproxy.wvu.edu/login.aspx?direct=true \&db=mah\&A $\mathrm{N}=85462177$.

De Sapio, Michael. "Beethoven and the Catholic Church." Crisis Magazine, September 7, 2016. Fr. Niecks. "An Analysis of Beethoven's "Missa Solemnis"." The Musical Times and Singing Class Circular 20, no. 439 (1879): 472-74. Accessed June 7, 2020. doi:10.2307/3356668.

Fr. Niecks. "An Analysis of Beethoven's "Missa Solemnis" (Continued).” The Musical Times and Singing Class Circular 20, no. 440 (1879): 515-17. Accessed June 7, 2020. doi: $10.2307 / 3356774$ 
Fr. Niecks. "An Analysis of Beethoven's "Missa Solemnis" (Continued)." The Musical Times and Singing Class Circular 20, no. 442 (1879): 638-41. Accessed June 7, 2020. doi: $10.2307 / 3357536$.

Fr. Niecks. "On Beethoven and His "Missa Solemnis"." The Musical Times and Singing Class Circular 20, no. 434 (1879): 193-95. Accessed June 7, 2020. doi:10.2307/3355603.

Keyser, Harry A. "Beethoven's Mass in D. A Fact Not Generally Known.” The Musical Times 51, no. 807 (1910): 307. Accessed June 7, 2020. doi:10.2307/906313.

Kinderman, William. "Beethoven's Symbol for the Deity in the "Missa Solemnis" and the Ninth Symphony.” 19th-Century Music 9, no. 2 (1985): 102-18. Accessed June 7, 2020. doi:10.2307/746576.

Kirkendale, Warren. "New Roads to Old Ideas in Beethoven's "Missa Solemnis"." The Musical Quarterly 56, no. 4 (1970): 665-701. Accessed June 7, 2020. www.jstor.org/stable/740932.

Lawrance, John W. "Beethoven's Mass in D." The Musical Times and Singing Class Circular 20, no. 440 (1879): 545. Accessed June 7, 2020. doi:10.2307/3356800.

Lester, Joel. "Revisions in the Autograph of the "Missa Solemnis Kyrie"." Journal of the American Musicological Society 23, no. 3 (1970): 420-38. Accessed June 7, 2020. doi:10.2307/830614.

Lilienstein, Saul E. “A Choral Director's Guide To Beethoven's Missa Solemnis.” The Choral Journal 7, no. 3 (1967): 18-21. Accessed June 7, 2020. www.jstor.org/stable/23542566. Lodes, Birgit. 1998. "Das Gloria in Beethoven's <Missa Solemnis>.” Edited by William (Reviewer) Drabkin. Music \& Letters 79 (4): 613-14. 
http://search.ebscohost.com.www.libproxy.wvu.edu/login.aspx?direct=true\&db=rih\&AN $=\mathrm{R} 24668$.

Lodes, Birgit. “'When I Try, Now and Then, to Give Musical Form to My Turbulent Feelings': The Human and the Divine in the Gloria of Beethoven's Missa Solemnis." Beethoven Forum in University of Nebraska Press 6, no. 1 (1998): 143-179. http://search.ebscohost.com.www.libproxy.wvu.edu/login.aspx?direct=true \&db=a9h\&A $\mathrm{N}=6446535$.

Ohl, John F. "Beethoven: “Missa Solemnis".” The Choral Journal 21, no. 6 (1981): 9-17. Accessed June 7, 2020. www.jstor.org/stable/23545680.

Thomas B. Crow. "Beethoven's Mass in D." Music \& Letters 32, no. 2 (1951): 203. Accessed June 7, 2020. www.jstor.org/stable/729382.

van Beethoven, Ludwig. "Beethoven Writes to the Imperial Prussian Embassy in 1823, Concerning “A Large Solemn Mass.” Bach 7, no. 4 (October 1976): 23-25. http://search.ebscohost.com.www.libproxy.wvu.edu/login.aspx?direct=true \&db=a9h\&A $\underline{\mathrm{N}=92019801 .}$.

\section{Theses and Dissertations:}

Briggs Roberts, Jeremy Ryan. "The Influence of Wolfgang Amadeus Mozart on the Creative Life and Output of Ludwig Van Beethoven: A Cross-Genre Investigation.” D.M.A. diss., University of Washington, Seattle, 2004. Proquest Dissertations and Theses Global.

Chong, Nicholas J. "Beethoven's Catholicism: A Reconsideration." Ph.D. diss., Columbia University, New York, 2016. Proquest Dissertations and Theses Global. 
Papanikolaou, Eftychia. "Profane Rites and Sacred Symphonies: Critical Perspectives on the Symphonic Mass.” Ph.D. diss., Boston University, Boston, 2001. ProQuest Dissertations and Theses Global.

\section{Periodicals:}

Beethoven, Ludwig van. 1976. "Litterae Ab Musicis: Beethoven Writes to the Imperial Prussian Embassy in 1823: Concerning 'a Large Solemn Mass.”' Bach 7, no. 4 (1976): 23-25. http://search.ebscohost.com.www.libproxy.wvu.edu/login.aspx?direct=true $\& d b=$ rih\&AN $=\mathrm{A} 1134947$.

Carr-Richardson, Amy. “Handel's Messiah as Model and Source for Beethoven’s Missa Solemnis.” Musicological Explorations 13 (March 2012): 93-126. http://search.ebscohost.com.www.libproxy.wvu.edu/login.aspx?direct=true \&db=rih\&AN $=\mathrm{A} 894884$.

Dolp, Laura. “Between Pastoral and Nature: Beethoven's Missa Solemnis and the Landscapes of Caspar David Friedrich.” Journal of Musicological Research 27, no. 3 (2008): 205-25. http://search.ebscohost.com.www.libproxy.wvu.edu/login.aspx?direct=true \&db=rih\&AN $=\mathrm{A} 590352$.

Drabkin, William. “The Sketches and Autographs for the Later Movements of Beethoven's Missa Solemnis.” Beethoven Forum 2 (1993): 97-132. http://search.ebscohost.com.www.libproxy.wvu.edu/login.aspx?direct=true $\& d b=$ rih \&AN $=\mathrm{A} 161255$. 


\section{Reviews:}

Beethoven, Ludwig van. "A Sketchbook from the Year 1821 (Artaria 197): Sketches for the Agnus Dei and Other Movements of the <Missa Solemnis>, the Piano Sonatas Op. 110 and Op. 111, and the Canon WoO 182.” Edited by William Drabkin and Barry (Reviewer) Cooper. Journal of the Royal Musical Association 138, no. 1 (2013): 175-85. http://search.ebscohost.com.www.libproxy.wvu.edu/login.aspx?direct=true \&db=rih\&AN $=\mathrm{R} 117690$.

Robinson, Ray. "Book Review.” The Choral Journal 21, no. 4 (1980): 25. Accessed June 7, 2020. www.jstor.org/stable/23545557.

Stickler, Larry W. "Book Review.” The Choral Journal 33, no. 7 (1993): 55. Accessed June 7, 2020. www.jstor.org/stable/23548589. 


\section{Franz Schubert (1797-1828)}

Considered a Romantic composer, Franz Schubert is included in this catalog because, as Dennis Shrock outlines, his choral music, especially the sacred settings, tend toward the classic style. The composition of church music faced many regulations by archbishops and these regulations influenced the musical characteristics for many composers. Schubert seems to have had some luck, as we read in Leo Black:

In 1783 the Emperor Joseph had banned elaborate, instrumentally accompanied church music except at the Imperial Chapel and certain specified churches. Vienna's cathedral (the Stephansdom) was commented on as having fallen behind in the repertoire and standard, for example by Vincent and Mary Novello in their Mozart Pilgrimage of 1829; fortunately Schubert's local Lichtental church was one of several in the suburbs where concerted music was allowed. It dated back a century and had a prosperous congregation well able to support a modest ensemble. The choir that sang there at the first performance of Schubert's earliest mass setting in 1814 is thought to have numbered between twenty-five and thirty including soloists, the orchestra very slightly more. ${ }^{40}$

${ }^{40}$ Black, Leo. Franz Schubert: Music and Belief. 2003. (Reprint: Great Britain: The Boydell Press, 2005), 30. 


\section{Bibliography}

\section{Book Chapters:}

Summer, Robert J. “Franz Schubert: Mass in G Major, D. 167.” In Choral Masterworks from Bach to Britten: Reflections of a Conductor, 65-70. 1941. Reprint, Maryland: Scarecrow Press, 2007.

\section{Journal Articles:}

Bennet, Joseph. “The Masses of Franz Schubert.” Dwight's Journal of Music 34, no. 11 (1874): 290-92. http://search.ebscohost.com.www.libproxy.wvu.edu/login.aspx?direct=true $\& d b=$ mpe \&A $\underline{\mathrm{N}=85993120 .}$.

Bennett, Joseph. "The Masses of Franz Schubert." Musical Times and Singing Class Circular, 1844-1903 16, no. 378 (1874): 571-574. http://www.libproxy.wvu.edu/login?url=https://search-proquestcom.www.libproxy.wvu.edu/docview/7320495?accountid=2837.

Cottrell, Willard. "Franz Schubert's Missa Solemnis.” The Choral Journal 23, no. 7 (1983): 3032. Accessed June 14, 2020. www.jstor.org/stable/23546180.

MacKay, Elizabeth Norma. "Schubert and the Church.” Choir \& Organ 5, no. 1 (1997): 11. http://search.ebscohost.com.www.libproxy.wvu.edu/login.aspx?direct=true $\& d b=$ mah \&A $\underline{\mathrm{N}=9701270991 .}$.

Thibodeau, Ralph. 1998. "Schubert: His Sacred Music_A Bicentennial Postscript.” Sacred Music 125 (1): 5-11. 
http://search.ebscohost.com.www.libproxy.wvu.edu/login.aspx?direct=true\&db=rih\&AN $=\mathrm{A} 156944$.

Van Hoorickx, Reinhard. "Schubert and the Bible.” The Musical Times 119, no. 1629 (1978): 953-55. Accessed June 14, 2020. doi:10.2307/960119.

\section{Theses and Dissertations:}

Cox, Richard Garner. "Choral Texture in the Music of Franz Schubert." Ph. D. diss., Northwestern University, Evanston, 1963. ProQuest Dissertations and Theses Global.

Mueller, Frank Frederick, Jr. “The Austrian Mass Between Schubert and Bruckner.” D.M.A. diss., University of Illinois at Urbana-Champaign, Urbana, 1973. ProQuest Dissertations and Theses Global.

Nafziger, Kenneth James. "The Masses of Haydn and Schubert: A Study in the Rise of Romanticism.” D.M.A. diss., University of Oregon, Eugene, 1970. ProQuest Dissertations and Theses Global.

Stringham, Ronald Scott. "The Masses of Franz Schubert." Ph.D. diss., Cornell University, Ithaca, 1964. ProQuest Dissertations and Theses Global. 


\section{D105 Missa in F Major (Missa Solemnis)}

Lichtental, 1814

Scoring: SSATTB soloists, SATB choir, 2 oboes, 2 clarinets in C, 2 bassoons, 2 horns in F, strings, 2 trumpets in $\mathrm{C}$, three trombones, timpani, strings, organ. There is also a version without the trumpets, trombones, and timpani.

Editions available on IMSLP: Breitkopf \& Härtel (1887) and Dirkjan Horringa (2013).

Publishers: Carus, Bärenreiter, Peters, G. Schirmer.

\section{Journal Articles:}

Prout, Ebenezer. "Franz Schubert's Masses.” The Monthly Musical Record 1, no. 1 (1871): 2-6. http://www.libproxy.wvu.edu/login?url=https://search-proquestcom.www.libproxy.wvu.edu/docview/7015602?accountid=2837.

Prout, Ebenezer. "Franz Schubert's Masses." The Monthly Musical Record 1, no. 1(1871): 13-16. http://www.libproxy.wvu.edu/login?url=https://search-proquestcom.www.libproxy.wvu.edu/docview/7066376? accountid=2837. 


\section{D167 Missa in G Major (Missa Brevis)}

Lichtental, 1815 (March)

Scoring: STB soloists, SATB choir, strings, organ.

Editions available on IMSLP: Breitkopf \& Härtel (1887).

Publishers: Bärenreiter, Carus, G. Schirmer.

\section{Journal Articles:}

Dorsey, Scott W. "Accuracy in Published Music: A Presentation of Errors in the Schubert "Mass in G” Published by Roger Dean.” The Choral Journal 31, no. 4 (1990): 25-29. Accessed June 14, 2020. www.jstor.org/stable/23547898.

\section{Theses and Dissertations:}

Albright, Lawrence Eugene. “A Comparison of Nine Selected Modern Editions of the Schubert Mass in G.” M.A. diss., San Jose State University, San Jose, 1995. ProQuest Dissertations and Theses Global.

De La Rosa, Louis Michael. "The Influence of Josephinism upon the Omission of Text in Schubert's “Mass in G”.” M.A. thesis, San Jose State University, San Jose, 1990. ProQuest Dissertations and Theses Global.

Johnson, Nathaniel Frederick. "Creation of Historically Informed Transcriptions for Chorus and Winds of Franz Schubert's Mass in G and Gabriel Fauré's Requiem.” D.A. diss., University of Northern Colorado, 2005. ProQuest Dissertations and Theses Global.

Ju, Kwangyoung. "Performance Practice in Franz Schubert's Mass in G, D167.” D.M.A. dissertation, University of California, Los Angeles, 1999. ProQuest Dissertations and Theses Global. 
Wakelin, Jan Walter, "Franz Schubert's "Mass in G": An Adaptation for Children's Choir and Keyboard.” M.A. thesis, California State University, Long Beach, 1982. ProQuest Dissertations and Theses Global. 


\section{D324 Missa in B-flat major (Hybrid composition between Missa Solemnis and Missa Brevis ${ }^{41}$ )}

Commission not known, 1815 (November)

Scoring: SATB soloists, SATB choir, 2 oboes, 2 bassoons, 2 trumpets in B-flat, timpani, strings, organ.

Editions Available on IMSLP: Breitkopf \& Härtel (1887).

Publishers: Bärenreiter, Breitkopf, Carus.

Journal Articles:

Prout, Ebenezer. "Franz Schubert's Masses."The Monthly Musical Record 1, (1871): 39-43. http://www.libproxy.wvu.edu/login?url=https://search-proquestcom.www.libproxy.wvu.edu/docview/7072902?accountid=2837.

${ }^{41}$ Black, Leo. Franz Schubert: Music and Belief. 2003. (Reprint: Great Britain: The Boydell Press, 2005$), 29$. 


\section{D452 Missa in C Major (Missa Brevis)}

Salzburg[?] 1816

Scoring: SATB soloists, SATB choir, 2 violins, basso continuo. Also scored for: 2 oboes OR 2 clarinets, 2 trumpets, timpani ad lib.

Editions Available on IMSLP: Breitkopf \& Härtel (1887).

Publishers: Bärenreiter, Breitkopf, Carus, G. Schirmer.

\section{Journal Articles:}

Black, Leo. "Late Thoughts from Schubert: The 1828 Replacement Benedictus for the C Major Mass.” The Musical Times 153, no. 1919 (2012): 31-39. Accessed June 14, 2020. Www.jstor.org/stable/41703514.

Prout, Ebenezer. "Franz Schubert's Masses.” The Monthly Musical Record 1, (1871): 53-57. http://www.libproxy.wvu.edu/login?url=https://search-proquestcom.www.libproxy.wvu.edu/docview/7066914?accountid=2837. 


\section{D678 Missa in A-flat major (Missa Solemnis)}

[?] 1819-1822

Scoring: SATB soloists, SATB choir, 1 flute, 2 oboes, 2 clarinets, 2 bassoons, 2 horns, 2 trumpets, 3 trombones, timpani, strings, organ.

Editions available on IMSLP: Breitkopf \& Härtel (1887) and Bärenreiter-Verlag (1980).

Publishers: Bärenreiter, Breitkopf, G. Schirmer.

\section{Journal Articles:}

Cottrell, Willard. “Franz Schubert's Missa Solemnis.” The Choral Journal 23, no. 7 (1983): 3032. Accessed June 14, 2020. www.jstor.org/stable/23546180.

Curtis, John J. "Franz Schubert's Mass in A b Major: A Consideration of the Composer's Revisions.” The Choral Journal 36, no. 7 (1996): 9-16. Accessed June 14, 2020. www.jstor.org/stable/23550724.

Denny, Thomas A. “The Years of Schubert's A-Flat-Major Mass, First Version: Chronological and Biographical Issues, 1819-1822.” Acta Musicologica 63, no. 1 (1991): 73-97. Accessed June 14, 2020. doi:10.2307/932888.

\section{Theses and Dissertations:}

Janower, David Michael. “A Conductor's Analysis for Performance of Franz Schubert's Mass in A-Flat Major (d 678).” D.Mus. Indiana University, Blomington, 1986. ProQuest Dissertations and Theses Global. 


\section{D950 Missa in E-flat Major (Missa Solemnis)}

Vienna, 1828

Scoring: SATB soloists, SATB chorus, 2 oboes, 2 clarinets, 2 bassoons, 2 horns, 2 trumpets, 3 trombones, timpani, strings.

Editions available on IMSLP: Breitkopf \& Härtel (1887) and Holograph Manuscript (n.d.).

Publishers: Breitkopf, Carus, Peters.

\section{Journal Articles:}

Burton, Sean M. "Revisiting Schubert's “Mass No. 6 in E-flat Major”, D. 950.” The Choral Journal 52, no. 1 (2011): 51-58. Accessed June 14, 2020. Www.jstor.org/stable/23560553.

Prout, Ebenezer. “Franz Schubert's Masses.” The Monthly Musical Record 1, (06, 1871): 69-72. http://www.libproxy.wvu.edu/login?url=https://search-proquestcom.www.libproxy.wvu.edu/docview/7073107?accountid=2837.

Prout, Ebenezer. “Franz Schubert's Masses.”The Monthly Musical Record 1, (07, 1871): 84-87. http://www.libproxy.wvu.edu/login?url=https://search-proquestcom.www.libproxy.wvu.edu/docview/7015994?accountid=2837.

\section{Theses and dissertations:}

DeWitt, Stanley David. "Franz Schubert's "Mass in E Flat": Analysis and Performance." M.M. thesis, California State University, Long Beach, 1988. ProQuest Dissertations and Theses Global. 
Knott, Josef Winston. “A Conductor's Analysis for Performance of Franz Schubert's Mass in EFlat Major D. 950.” D. Mus. diss., Indiana University, Bloomington,1988. ProQuest Dissertations and Theses Global. 


\section{Findings}

To find the resources to compose this catalog was more challenging than initially thought. Many materials provide in-depth information in specific subjects, such as books about single masses, for example, Beethoven Missa Solemnis (included in the Beethoven section), and

the book about all the masses of F.J. Haydn (included in the Haydn section). However, the literature found considering the limitations of what is available online not including dissertations, does not represent significant material that can provide broader, complete, and more in-depth information of the mass genre. For example, students in a graduate level choral literature class or professional conductors who might want to specialize in the genre will not find a comprehensive textbook specialized in the Roman Catholic Ordinary Masses. The entry on Grove Music Online by Joseph Dyer (included in chapter one) offers an overview of the musical masses in more general terms from the 16th century in Europe up until the 20th century, including a topic about countries beyond Europe. That might be a starting point helping to situate a beginning scholar in the realm of masses.

The information on masses, composers, period, and style, are available. Still, the researcher will need to explore many resources and put a puzzle together to find answers that could be, otherwise, pieced together and answered with a more detailed and specialized book. It is indeed a vast subject that would require long-term research, but it would be, in fact, valuable material to the history of sacred choral music. 
The greatest challenge in researching and writing this document was to identify the masses of composers beyond the famous Austrian composers, Michael and Joseph Haydn, W.A. Mozart, Beethoven, and Schubert. Luigi Cherubini is the only non-Austrian composer that appeared in the Holmer Ulrich book, A Survey of Choral Music, which is a book mostly about sacred music throughout the eras with great attention to masses. Choral Repertoire by Shrock is a book that offers a catalog of composers with some bibliographical information and a list of repertoire (when the collection is considered significant for the choral literature). Despite being one of the most comprehensive books on choral repertoire, it only presents a sum of seven classical composers from France and Italy, including Gioacchino Rossini, who was a much later composer. He is the only one to have pieces included in this particular catalog. Other than what was available in the MacIntyre dissertation mentioned several times in the previous chapter, no other comprehensive research on composers and works beyond the most well-known composers was found while conducting research for this document.

While this document mostly provides the reader with a bibliography of well-known composers and works that are already available, the value of this collection is the accessibility of a large number of resources allowing for a fundamental understanding of the mass genre during this time, including the structure and the form of the genre of the classical period. Even though each composer will have their particular characteristics, the fundamental knowledge can be translated and adapted to virtually any other piece of the same genre, in this case, the mass ordinary.

The findings of this document might not be an exhaustive listing of the available bibliographic materials regarding the masses of the classical composers. However, this is a 
starting point for more comprehensive research that will aim to provide a book (or a collection of them in a long-term period) that contains detailed information in a textbook format for academic students in higher levels of music education. This document serves to open a window to this important study. My goal is that, in a few years, this material will be revised and will become available to the general public of music students and scholars in a textbook format. 